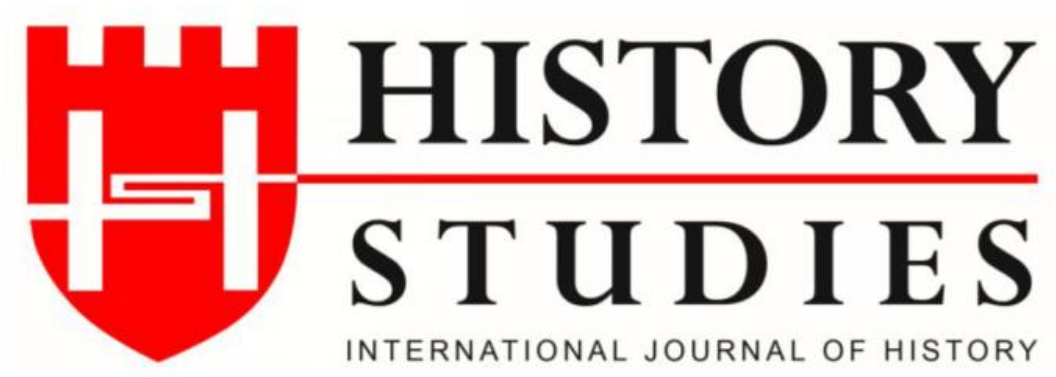

ISSN: 13094173 (Online) 1309 - 4688 (Print)

Volume 12 Issue 5, October 2020

DOI Number: 10.9737/hist.2020.924

Araştırma Makalesi

Makalenin Geliş Tarihi: 08.06.2020 Kabul Tarihi: 27.07.2020

Atıf Künyesi: Alifer Çiftçi, “Artemision Deniz Savaşı: Yeni Bir Değerlendirme”, History Studies, 12/5,

Ekim 2020, s. 2371-2394.

\title{
Artemision Deniz Savaşı: Yeni Bir Değerlendirme*
}

\author{
The Naval Battle of Artemision: A New Assessment
}

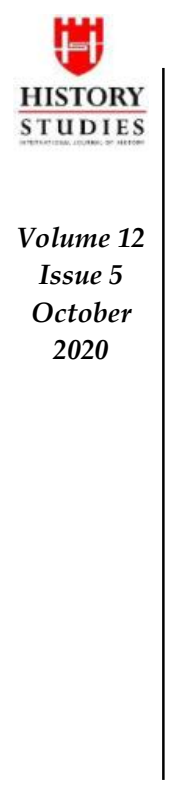

\author{
Alifer Çiftci \\ ORCID No: 0000-0003-1904-4639 \\ Kırklareli Üniversitesi
}

\section{$\ddot{O} \mathbf{z}$}

Persler ile Yunan kentleri arasındaki mücadele iki yüz yıldan daha uzun bir süre devam etmiş olsa da bu süreçte en önemli savaşlar Perslerin Yunan anakarasını MÖ 490 ve 480/479'da ele geçirmeye çalıştığı sırada yaşanmıştır. Açıkçası Pers Kralları Dareios I (MÖ 522-486) ve Kserkses (MÖ 486-465), Yunanistan'ı hâkimiyet altına alıp imparatorluk sınırlarını genişletmek istemiştir. Bu doğrultuda Pers saldırılarının stratejik ve taktiksel problemleri, her yönüyle araştırmacılar tarafından tetkik edilmiş olup günümüzde de incelenmeye devam edilmektedir. Bu tür problemlere bir örnek, Herodotos'un Artemison Savaşı'na dair anlatımıdır. Amacımız antik kaynaklar ile araştırmacıların öne sürdüğü görüşler çerçevesinde Artemision Savaşı'nın amacı ve safhalarını ayrıntılı ve daha açık bir şekilde ortaya koymaktır.

Anahtar Kelimeler: Persler, Yunanlılar, Artemision

\begin{abstract}
Although the struggle between the Persians and the Greek cities continued for more than two centuries, in this period the most important battles happened in the years of 490 and 480 or 479 $\mathrm{BC}$ when the Persians tried to obtain the Greek mainland. Obviously, the Persian kings Darius I (522-486 BC) and Xerxes (486-465 BC) wanted to expand the borders of their empire by taking Greece under their rule. Accordingly, the strategic and tactical problems of the Persian attacks were analyzed by the researchers at all points and they have continued to be studied in the present day. The narration of Herodotus regarding the Naval Battle of Artemision is an example for the aforesaid problems. We aim to reveal the objectives and phases of the Battle of Artemision, in detail and more obviously, within the frame of the points of view which were asserted by the researchers.
\end{abstract}

Keywords: The Persians, The Greeks, Artemision

\footnotetext{
* Bu makale Alifer Çiftci'nin Muğla Sitkı Koçman Üniversitesi Tarih Bölümü Eskiçağ Tarihi Anabilim Dalı'nda, Prof. Dr. Muzaffer Demir'in danışmanlığında yapmakta olduğu Antikçağ Akdeniz Dünyasında Deniz Savaşları MÖ 600400 başlıklı doktora tezinden elde edilmiștir.
} 


\section{Giriş}

MÖ 490 yılında Marathon'da alınan yenilgi sonrasında Atinalılara daha da öfkelenen I. Dareios, derhal yeni bir seferin hazırlıklarına başlamıştır. Kral, hâkimiyeti altındaki tüm yerlere öncekinden daha fazla gemi, at, malzeme ve nakliye gemisi hazırlamaları konusunda haberciler yollamıştır. Savaş için hazırlıklar üç yıl sürmüş olup dördüncü yıl, gerek Mısır'daki ayaklanma gerekse kralın oğulları arasında başlayan taht kavgası, Yunanistan seferinin ertelenmesine neden olmuştur. I. Dareios'un MÖ 486' daki ölümüyle yerine oğlu Kserkses tahminen otuz iki yaşında Pers tahtına geçmiştir. Öncelikli olarak Mısır ile stratejik konumdaki Babil'de ortaya çıkan isyanların bastırılması ve güvenliğin sağlanmasıyla birlikte Kserkses, Yunanistan'a karş1 yapılacak seferin hazırlıklarına devam etmiştir.

Diğer taraftan Kserkses'in yapacağı sefer öncesinde Yunanlılar, tam anlamılla ortak bir görüş birliğine sahip değildi. Zira Thessalia'daki yerleşimler ve Thebai gibi pek çok kent, Büyük Kral'a boyun eğmiş ve bağlılığın bir sembolü olarak "toprak ve su” armağanını sunmuştu. Sparta'nın başı çektiği diğer grup, MÖ 481 yılı sonbaharında düşman saldırısına karşı alınacak tedbirleri görüşmek için Korinthos'taki Isthmos'a (Korinthos Kıstağı) delegeler gönderip bir Yunan Birliği meydana getirmişlerdir. Isthmos'ta yapılan toplantının bir sonucu olarak kent devletleri, öncelikle kendi aralarındaki düşmanlıklara ve savaşlara son verip uzun süreli bir müttefiklik için yemin etmişlerdir. Akabinde Yunanlılar, Perslere karşı denizde Artemision karada Thermopylai olmak üzere mücadele etme kararı almışlardır.

Herodotos, Yunan donanmasının tüm çabasının Euripos'un güvenliği; Leonidas komutasındaki kuvvetlerin de Thermopylai'deki dar geçidi korumak olduğunu belirtip Artemision ve Thermopylai arasında bir bağlantı kurmuştur. ${ }^{1}$ Buna karşın bazı araştırmacılar, hem Artemision hem de Thermopylai'deki kara ve deniz gücü sayısına vurgu yaparak Yunanlıların oradaki asıl çabasının Salamis ile Isthmos'ta savunma için daha fazla gemi ve birlik toplanıncaya kadar düşman faaliyetlerini engellemek ya da Atinalılara tahliye için gereken zamanı kazandırmak olduğunu ileri sürmüşlerdir. ${ }^{2}$ Kimileri ise, Yunanlıların Artemision'da daha sonradan MÖ 480 yılındaki Salamis Savaşı'nda başarıyla uyguladıkları "dar sular" stratejisini benimsediğini belirtip onların Pers donanmasını Oreos Kanalı'nın güneyindeki sulara çekip daha fazla gemiye sahip olan düşmanın manevra hareketlerini sınırlamayı umdukları; ancak bu planlarının Persler tarafından fark edildiğini iddia etmişlerdir. ${ }^{3}$ Diğerlerine göre Yunanlıların oradaki esas amacı, Oreos Kanal1 ${ }^{4}$ ya da Euripos boyunca Kserkses'e ait gemilerin geçişine engel

\footnotetext{
${ }^{1}$ Herodotos, Historiae (Herodot Tarihi), çev., M. Ökmen, Türkiye İş Bankası Kültür Yayınları, İstanbul 2016, VIII. 15. 2, 21. 1 .

${ }^{2}$ M. H. Jameson, "Waiting for the Barbarian: New Light on the Persian Wars", Greece\&Rome, Vol. 8, No. 1, Mar. 1961, s. 11; J. F. Lazenby, "The Strategy of the Greeks in the Opening Campaign of the Persian War", Hermes, Bd. 92, H. 3, 1964, s. 267-268; J. A. S. Evans, "Notes on Thermopylae and Artemisium", Historia, Bd. 18, H. 4, Aug. 1969, s. 391, 393, 405.

${ }^{3}$ R. Custance, War At Sea: Modern Theory and Ancient Practice, William Blackwood and Sons, Edinburg and London 1919, s. 13-14; S. Sidebotham, "Herodotus on Artemisium", The Classical World, Vol. 75, No. 3, Jan.-Feb., 1982, s. 177-179.

${ }^{4}$ R. G. Macan, Herodotus: The Seventh, Eighth and Ninth Books, Cambridge University Press, Oxford 2010, s. 280; Philip de Souza, The Greeks and Persian Wars 499-386 BC, Routledge, New York and London 2012, s. 49.
} 
olmaktır. ${ }^{5}$ Açıkçası Artemision'daki genel stratejinin kendisi açık olmasına rağmen onunla ilgili birtakım anlatımlar bu stratejinin anlaşılmasını güçleştirmektedir. ${ }^{6}$

Herodotos'a göre, Korinthos'ta bir araya gelen Yunanlılar Perslere karşı nerede ve nasıl savaş1lacağ1 konusundaki görüşmeler neticesinde karada Thermopylai; ${ }^{7}$ denizde ise, Artemision'da mücadeleye karar vermişlerdir. ${ }^{8} \mathrm{Bu}$ doğrultuda, gerek Artemision, gerekse Thermopylai' nin coğrafi yapısının bilinmesi yaşanan mücadelenin daha iyi anlaşılması açısından faydalı olacaktır. Herodotos, Yunanlıların Kuzey Euboia'da (Eğriboz) yer alan Artemision'u Thermopylai'ye olan yakınlığından dolayı seçtiklerini ve böylelikle her iki tarafın, birbiriyle yakın temas sağlayabileceğini düşündüklerini dile getirmiştir. ${ }^{9}$ Buna göre, bahsi geçen her iki nokta birbirine yakın olup aralarındaki uzaklık yaklaşı $41 \mathrm{~km}$ ' dir. ${ }^{10}$ Thermopylai, Thessalia'ya açılan geçitten daha dar olup tek bir boğazdan meydana gelmektedir ve en önemlisi de burası Yunanlıların yurtlarına yakın olup düşmanın Yunanistan'a ilerleyişinin engellemesi açısından mühim bir noktadır. ${ }^{11}$ Zira Kserkses'in ordusunun Thessalia üzerinden Yunanistan'ın merkezine geçebileceği tek yol burasıdır. Aynı zamanda Phokisliler tarafından Thessalialılara karşı inşa edilmiş yaklaşık $200 \mathrm{~m}$ uzunluğunda eski bir savunma duvarının bulunduğ ${ }^{12}$ ve orta bölümünde sadece 15 m genişliğe sahip olan bu geçit, ${ }^{13}$ Yunanlılar açısından Pers kuvvetlerinin kanatlarını açmasını ve süvarilerinin tam olarak hareket etme olanağını kısıtlaması ve mevcut en iyi savunma mevki olması sebebiyle stratejik bir öneme sahiptir. ${ }^{14}$

Diğer taraftan Yunanlılar, Perslerin denizde takip ettikleri rotayı bilmediklerinden ve onların gerek destek bulma ümidiyle gerekse güneyden Boiotia kıyılarına ulaşmak için ada rotasını Skiathos, Peparethos, Skyros ve Andros'u- izleyebileceğini düşündüklerinden ötürü Artemision'a donanma göndermeye karar vermişlerdir. Böylelikle bahsi geçen rotanın Pers donanması tarafından kullanımını engellenmek isteyen Yunanlılar, düşmanı yandan kuşatabilir ve Makedonya ile olan iletişimini kesebilirdi. Dahası Yunan donanması sayesinde Euboia'daki

Volume 12

Issue 5

October

\footnotetext{
5 W. K. Prentice, "Thermopylae and Artemisium", Transactions and Proceedings of the American Philological Association, Vol. 51, 1920, s. 16-17; A. Ferrill, "Herodotus and the Strategy and Tactics of the Invasion of Xerxes", The American Historical Review, Vol. 72, No. 1, Oct. 1966, s. 110; J. M. Balcer, The Persian Conquest of the Greeks 545-450 B. C., Konstanz 1995, s. 249; A. M. Mansel, Ege ve Yunan Tarihi, Türk Tarih Kurumu, Ankara 2011, s. 281. ${ }^{6}$ Ferrill, age, s. 102-104; J. B. Bury, "The Campaign of Artemisium and Thermopylae", The Annual of the British School at Athens, Vol. 2, 1895/96, s. 84, 86-88; G. B. Grundy, "Artemisium”, Journal of Hellenic Studies, Vol. 17, 1897, s. 213-214; Evans, "Notes on Thermopylae and Artemisium", s. 389; Sidebotham, agm, s. 177.

${ }^{7}$ N. G. L. Hammond, A History of Greece to 322 B. C., Oxford 1989, s. 231; C. Carey, Thermopylae, Oxford University Press, s. 23-25; Thermopylai, sıcak kükürtlü sularından dolayı "sıcak kapılar" anlamına gelmektedir.

${ }^{8}$ Hdt. VII. 175. 1-177. 1; Lysias, Lysias, Trans., W. R. M. Lamb, Cambridge-Massachusetts 2000, II. 30-31; C. Hignett, Xerxes' Invasion of Greece, Clarendon Press, Oxford 1963, s. 113-115; K. S. Sacks, "Herodotus and Dating of the Battle of Thermopylae", The Classical Quarterly, Vol. 26, No. 2, 1976, s. 238-247; J. L. Myres, Herodotus: Father of History, Oxford University Press, Oxford 1999, s. 247-250.

${ }^{9}$ Hdt. VII. 175. 1-2; 177. 1; Ayrica bkz. Plutarkhos, Bioi Paralelloi: Themistokles, Trans., B. Perrin, Loeb Classical Library, Cambridge, Mass.-London, 1914, VIII. 2-3; Bury, agm, s. 84-86; Hignett, age, s. 150-151; J. Zacharias van Rookhuijzen, Herodotus and the Topography of Xerxes' Invasion: Place and Memory in Greece and Anatolia, Walter de Gruyter GmbH \& Co KG 2018, s. 136-139.

${ }^{10}$ Sidebotham, agm, s. 182.

${ }^{11}$ Diodoros, Bibliotheke Historike: Diodorous of Sicily, Trans., C. H. Oldfather, vol. I-VI; C. H. Sherman, vol. VII; C. B. Welles, vol. VIII; R. M. Geer, vol. IX-X; F. R. Walton, vol. XI-XII, The Loeb Classical Library, Cambridge, Mass.-London 1933-2004, XI. 4. 1; J. F. Lazenby, The Defence of Greece 490-479 B. C., Aris\&Phillips, Warminster, 1993, s. 117.

${ }^{12}$ Carey, age, s. 27-29.

${ }^{13}$ Hdt. VII. 176. 4; Souza, age, s. 51; Rookhuijzen, age, s. 156-158.

${ }^{14}$ Hdt. VII. 177. 1; Cornelius Nepos, On the Great Generals of Foreign Nations (Ünlü Kişilerin Yaşamlart), çev., Ü. Fafo Telatar, Arkeoloji ve Sanat Yayınları, İstanbul 2016, II. 3. 1-2 'Themistokles'; Diod. XI. 6. 4; A. R. Burn, Persia and the Greeks: The Defence of the West, c. 546-478 B.C., London 1962, s. 380.
} 
müttefikler de korunmuş olacaktı. ${ }^{15}$ Bununla birlikte, Artemision'un bir diğer özelliği savaş gemilerinin düz kumsala kadar çekilebilmesine ek olarak kıyı yakınlarında gemiler için hiçbir engelin bulunmamasıdır. Aynı zamanda Artemision birden $20 \mathrm{~m}$ derinleștiğinden ötürü, gemileri denize indirme açısından kolay olup ${ }^{16}$ büyük, korunaklı ve içme suyu kaynakları bakımından zengin bir alandır. ${ }^{17}$

\section{1- İlk Temas}

Artemision Savaşı'nın başlangıcına yönelik olarak Herodotos'un anlatımı, Kserkses'in Therma' da (ya da Therme/Thessaloniki) toplanan donanmasın $1{ }^{18}$ korumak ya da izlenen rotanın güvenliğini sağlamak üzere biri Sidonlulara ait en hızlı gemilerinden 10 tanesini keşif için Skiathos Adası'na göndermesidir. ${ }^{19}$ Buna göre, Skiathos'ta gözcülük için bekleyen üç Yunan gemisi, yaklaşmakta olan bu Pers gemilerini görür görmez kaçmaya başlamıştır. Persler, biri Troizen diğeri Aigina olmak üzere iki keşif gemisini yakalamış ve mürettebatını esir almıştır. Atinalı kaptan Phormos'un idaresindeki üçüncü gemi, Peneios'a (Makedonya, Tempe Nehri) kadar kaçmış ve orada karaya oturmuştur. Mürettebat ise, gemiyi terk edip Thessalia üzerinden Atina'ya dönmüsstür. ${ }^{20} \mathrm{Bu}$ hadise Pers donanmasındaki en hızlı gemilerin küreğe bağlı sürat üstünlügünü göstermekle ${ }^{21}$ birlikte, bazı Pers gemilerinin Yunan gemilerine kıyasla daha hafif olduğunun bir işaretidir. ${ }^{22}$ Bahsi geçen başarının bir sonucu olarak Persler, savaşın başında rakip donanmanın gücüne ve hatta savaş planına dair yeterince bilgi elde etmiş olmalıdır. Akabinde, Skiathos'taki Yunanlılar ateş işaretleriyle Artemision'da demirli halde bekleyen ana filoya

\footnotetext{
${ }^{15}$ Diod. XI. 13. 2.

${ }^{16}$ N. G. L, Hammond, "The Expedition of Xerxes”, The Cambridge Ancient History, vol. IV, Ed. John Boardman, N. G. L. Hammond, D. M. Lewis, Cambridge University Press, Cambridge 2008, s. 550.

17 B. Strauss, The Battle of Salamis: The Naval Encounter that Saved Greece-and Western Civilization Simon \&
} Schuster, 2005, s. 14-15; Rookhuijzen, age, s. 137.

${ }^{18}$ Hdt. VII. 124. 1.

${ }^{19}$ Hdt. VIII. 92. 1; Burn, age, s. 386; O. Rees, Great Naval Battles of the Ancient Greek World, Pen \& Sword 2018, s. 20.

${ }^{20}$ Hdt. VII. 179. 1-182. 1; Lazenby, "The Strategy of the Greeks in the Opening Campaign of the Persian War", s. 275; Yunan donanmasının Artemision'dan ayrılmasının ardından Perslere ait 10 gemiden üçü, Skiathos ile Magnesia arasında yer alan Myrmex/Karınca (Lefteri ya da Lefkari) Kayalığı'na ilerleyip yanlarında getirmiş oldukları bir taş sütunu oraya dikmişlerdir. Bu kayalığın yerini gösteren ise, Skyroslu Pammon idi. Bu konuda bkz. Hdt. VII. 183. 13; Rookhuijzen, age, s. 120-121; Herodotos'un bahsettiği bu taş sütun, muhtemelen arkadan gelecek olan Pers gemilerinin kayalığa çarparak zarar görmesini engellemek amacıyla dikilmiştir.

${ }_{21}^{21}$ J. S. Morrison-J. F. Coates- N. B. Rankov, The Athenian Trireme, Cambridge University Press, Cambridge 2000, s. 50; Hammond, "The Expedition of Xerxes", s. 547.

${ }^{22}$ Salamis Savaşı'ndaki (MÖ 480) Atina gemilerine ilişkin gerek Thukydides'in “ ... Salamis'te mücadele eden bu gemiler, tamamen güvertesizdi" ifadesi gerekse Plutarkhos'un bu gemilere dair " Themistokles tarafindan hiz ve manevra için çok iyi biçimde inşa edilmişti" vurgusu gemiler arasındaki önemli bir farkı ortaya koymaktadır. Buna göre, Atina trieresleri savaş esnasında belli bir manevra dâhilinde düşman gemilerini hasara uğratmak maksadıyla daha hızlı ve yüksek hareket kabiliyetine sahip olacak şekilde inşa edilmiştir. Doğrusu Yunan trieresleri, genel anlamda aynı tasarıma sahip olsalar da Themistokles'in tasarımındaki teknik bir özellikten dolayı Atina trieresleri en hızlılarıdır. Buna karşın MÖ 483 yılında aceleyle başlattıkları gemi inşa programının sonucunda Atinalılar, kerestenin kuruması için gerekli zamanı bulamamışı ve dolayısıyla inşa edilen trieresler, Pers donanması içerisindeki gemilere kıyasla daha ağır durumdaydı. Bu konuda bkz. Hdt. VIII. 42. 2; Thukydides, Historiae (Peloponnesos Savaşı), çev. T. Gökçöl, Hürriyet Yayınları, İstanbul 1976, I. 14. 3; Plutarkhos, Bioi Paralelloi: Kimon, Trans., B. Perrin, Loeb Classical Library, Cambridge, Mass.-London, 1914, XII. 2; Vegetius, Epitoma rei Militaris: Epitome of Military Science, Trans., N. P. Milner, Liverpool University Press, Liverpool, 1996, IV. 35-36; Vitruvius, De Architectura (Mimarlık Üzerine On Kitap), çev., S. Güven, Şevki Vanlı Mimarlık Vakfı Yayınları, İstanbul 2015, II. 9. 1-4; Plinius Secundus, Naturalis Historia, Natural History, Trans., J. H. R. Rackham, W. H. S. Jones, D. E. Eichholz, Vol. I-X, The Loeb Classical Library, Cambridge, Mass.-London 1938-1971, XVI. 74 [188-192]; R. Meiggs, Trees and Timber in the Ancient Mediterranean World, Oxford University Press, 1982, s. 126, 349; E. N. Borza, "Timber and Politics in the Ancient World: Macedon and the Greeks", Proceedings of the American Philosophical Society, Vol. 131, No. 1, 1987, s. 38; Rees, age, s. 21. 
yaşanan bu olayları haber vermişlerdir. Bu noktada Herodotos, korkuya kapılan Yunanlıların Artemision'dan demir alıp Euripos'u korumak amacıyla Khalkis'e doğru yelken açtıklarını söylemektedir. ${ }^{23} \mathrm{Bu}$ bağlamda şu soruların cevaplandırılması elzemdir: a) Yunanlılar, niçin Euripos'u korumak zorunda kalmışlardır? b) Yunan donanması (tamamı ya da bir kısmı), gerçekten Pers kuvvetlerinden korktuğu için mi yoksa düşmana ait 200 geminin (VIII. 6. 1-7. 2) Euboia etrafını dolaşacağını öğrenmesinden ötürü mü Khalkis'e hareket etmiştir?

Herodotos'un (VII. 183. 1) Yunan donanmasının ilk geri çekilişine ${ }^{24}$ dair anlatımı, birçok modern araştırmacıyı tatmin etmediği için, farklı görüşler ortaya atılmıştır. Bu bağlamda Herodotos'un anlatımına uygun şekilde Myres ve Strauss, muhtemelen Yunanlıların Euboia'nın doğu kıyısındaki Skiathos'tan aşağıya doğru bir Pers hareketinden şüphelendiklerini ve buna bağlı olarak düşmanla savaşmak için Khalkis'e gitmekte acele ettiklerini varsaymışlardır. ${ }^{25}$ Bir diğer olasılık, Yunanlıların bölge hakkındaki bilgileri sayesinde tehlikeli bir firtınanın çıkacağını anladıkları ${ }^{26}$ ve bu nedenle korunaklı bir mevkiye çekilmek zorunda kalmış olduklarıdır. ${ }^{27}$ İkinci görüşe karş1 çıkanlar öncelikle Yunanlıların doğudan patlayan ani ve şiddetli bir firtına ${ }^{28}$ sırasında epey tehlikeli görünen Oreos Kanalı üzerinden Euripos'a yelken açmak yerine Artemision'da gemileri güvenli şekilde karaya çekebileceklerini iddia etmişlerdir. Ayrıca Yunanlılar Euripos yönünde geri çekilirse, Pers donanması güneye yelken açmak için bir olanak bulacaktı ve bundan dolayı Persler, Thermopylai düşene kadar Yunan gemilerini uzak tutarak bu yerin arkasını koruyan birliklere karşı amfibi harekâtlar yürütebilecekti. ${ }^{29}$ Dolayısıyla bu durum Yunanlılar açısından büyük tehlike yaratacaktı. Hignett ve Hammond da aynı şekilde, Herodotos'un bu varsayımının hatalı olduğuna değinip Yunanlıların belki de ateş işaretlerini yanlış anlamış olduklarını; zira Leonidas'ın bulunduğu yerin arka kısmına denizden düşman birliklerinin çıkarma yapabileceklerine dikkat çekmişlerdir. ${ }^{30}$ Yukarıda belirtildiği gibi, bazı araştırmacılar Yunanlıların Pers donanmasını Euboia ile anakara arasındaki Oreos Kanalı'nın güneyindeki dar boğaza çekmek istediği için böyle bir harekete giriştiğini; ancak Persler tarafından niyetlerinin fark edilmesinden sonra Euboia'nın kuzeyindeki daha geniş sularda savaşın gerçekleştiğini öne sürmüşlerdir. ${ }^{31}$ Bir diğer görüş ise, Peneios'a giden Yunanlıların Thessalia üzerinden geri döndükleri kanıt gösterilip Leonidas'ın henüz Thermopylai'de olmadığından hareketle Yunanlıların rahatlıkla Khalkis'e gitmiş olabileceği yönündedir. ${ }^{32}$

Herodotos'a göre, Yunanlılar Artemision'dan ayrılırken Pers donanması da herhangi bir zorlukla karşılaşmadan Therma'dan çıkıp üç ya da dört gün sonra Kasthanaia kenti ile Sepias

${ }^{23}$ Hdt. VII. 183. 1; Plutarkhos, Moralia: Plutarch's Moralia, Trans., F. C. Babbith-W. C. Helmbold, vols. I-XIV, Loeb Classical Library, Cambridge, Mass.-London 1928-1967, XI. 867 b; Lazenby, "The Strategy of the Greeks in the Opening Campaign of the Persian War", s. 275.

${ }^{24}$ Herodotos, eserinde Yunan donanma komutanlarının üç ayrı sebepten ötürü Artemision'dan geri çekilmeyi tasarlamış olduklarını ya da fiili olarak bunu gerçekleştirdiklerini belirtmiştir: İlk olarak Thessalia kıyısı açıklarında 3 Yunan keşif gemisinin ele geçirildiği haberinin akabinde Khalkis'e hareket. İkincisi, Yunanlılar Aphetai'ye demirlemiş olan Pers gemilerinin sayısını gördüklerinde. Son olarak da savaşın üçüncü gününde, yani Thermopylai'nin düştüğü haberinin alınması üzerine. Bkz. Sidebotham, agm, s. 180.

${ }^{25}$ Myres, age, s. 257; Strauss, age, s. 18-19.

${ }^{26}$ Veg. epit. rei. mil. IV. 41.

${ }^{27}$ G. B. Grundy, The Great Persian War and Its Preliminaries: A Study of the Evidence, Literary and Topographical, London 1901, s. 323-324; Burn, age, s. 387; Balcer, age, s. 253; G. Cawkwell, The Greeks Wars: The Failure of Persia, Oxford University Press, Oxford 2005, s. 94.

${ }^{28}$ Hdt. VII. 188. 2.

${ }^{29}$ Macan, age, s. 277; Sidebotham, agm, s. 181.

${ }^{30}$ Hignett, age, s. 162; Hammond, "The Expedition of Xerxes", s. 551; Böyle bir iddianın eksik yanları için bkz. Lazenby, "The Strategy of the Greeks in the Opening Campaign of the Persian War", s. 275-276.

${ }^{31}$ Sidebotham, agm, s. 177-182.

${ }^{32}$ Lazenby, "The Strategy of the Greeks in the Opening Campaign of the Persian War", s. 277. 
Burnu arasındaki Magnesia'ya yanaşmıştır. ${ }^{33}$ Adı geçen yere ilk gelen Pers gemileri, kıyıya yakın demirlerken arkadan gelenler de onlara yakın yerlerde demirlemiştir. Herodotos, sahil pek büyük olmadığından gemilerin sekiz saf halinde derinliğe dizildiklerini ve bu nedenle açık denize doğru çıkıntı yaptıklarını belirtmiştir. Gece sakin geçmesine rağmen ertesi sabah başlayan ve üç gün boyunca şiddetli şekilde devam eden firtına, 400 Pers gemisinin batmasına ve birçok insanın ölmesine neden olmuştur. Bununla birlikte, yerlilerin 'Hellespontoslu' ismini verdikleri bu firtına sayısız ikmal gemisinin yanı sıra başka gemileri de yok etmiştir. Fırtınaya açık denizde yakalanmayanlar ise, gemilerini karaya çekip kendilerini ve gemilerini kurtarmıştır. Persler, firtınanın sona ermesinin ardından gemilerini denize indirip öğleden sonra Aphetai'ye ulaşmıştır. ${ }^{34}$

Euboia tepelerine yerleştirilen gözcüler, firtınanın azaldığı ikinci gün Yunanlılara gelip Pers donanmasının yaşadığı felaketi haber vermişlerdir. Bunun üzerine kurtarıcı olarak Poseidon'a dua eden Yunanlılar, az sayıda düşman gemisinin kalmış olacağı umuduyla ikinci defa Artemision'a hareket edip orada üslerini kurmuştur. ${ }^{35}$ Firtına dindikten hemen sonra, yani dördüncü gün ana filodan geri kalan 15 gemi Yunan donanması tarafından ele geçirilmiştir. Filo komutanı Thamasios oğlu Sandokes başta olmak üzere, Alabanda tiranı Aridolis ve Paphoslu kaptan Demonoos oğlu Penthylos gibi önemli kişiler sorguya çekilip Pers gücüne dair istenen bilgiler alındıktan sonra Korinthos'a gönderilmiştir. ${ }^{36}$

Herodotos'un bahsettiği firtınaya bağlı büyük kaybın aksine Tarn, Aphetai'de ${ }^{37}$ Pers donanmasının 450 trieresi geçmediğini ve belki orada daha azının olabileceğini belirtip fırtına neticesinde Perslerin kaybının 20-30 trieres arasında olduğunu ifade etmiştir. ${ }^{38}$ Kimi araştırmacılar ise, bu firtına sahnelerinin abartıldığını ya da uydurulduğunu iddia etmiştir. ${ }^{39}$

Herodotos'un “...[Yunanlılar] Korkuya kapıldıkları için Euboia'nın yüksek yerlerine gözcüler bırakıp Artemision'dan demir aldılar ve Euripos'u korumak amacıyla Khalkis'e doğru

\footnotetext{
${ }^{33}$ Hdt. VII. 183. 3; 188. 1; Bury, agm, s. 95-97; W. W. Tarn, "The Fleet of Xerxes", The Journal of Hellenic Studies, Vol. 28, 1908, s. 210-215; Balcer, age, s. 250; Herodotos'un bahsettiği üzere, Pers donanmasının Therma'dan Sepias'a kadarki yaklaşık 90-100 mil (144.84/160.93 km) arasındaki mesafeyi tek bir günde katetmesi kabul edilemez. Ayrıca, Pers donanmasının toplu halde hareket etmesi de yanlıştır. Bkz. Hignett, age, s. 168-169, 172-175; W. W. How-J. Wells, A Commentary on Herodotus, Vol. II, Oxford 1991, s. 210; Balcer, age, s. 249. Bu arada, Kserkses'in ordusunun başında Therma'dan çıkışının on birinci günü olup Thermopylai'e kadar toplam yürüyüş 13 gün sürmüştür. Persler yaklaşık 6 gün boyunca orada kalmıştır. Bkz. Hdt. VII. 183. 2-3; F. Maurice, "The Size of the Army of Xerxes in the Invasion of Greece 480 B. C", Journal of Hellenic Studies, Vol. 52, 1930, s. 233.

${ }^{34}$ Hdt. VII. 188. 1-193. 2, 236. 2; VIII. 6. 1; Strabon, Geographika: The Geography of Strabo, Trans., H. L. Jones, Vol. I-VIII, The Loeb Classical Library, London and New York 1917-1932, IX. 5. 22; Diod. XI. 13. 1-2; Grundy, age, s. 325; P. Green, The Greco-Persian Wars, University of California Presss, Berkeley \& Los Angeles 1996, s. 117; J. D. Mikalson, Herodotus and Religion in the Persian Wars, The University of North Caroline Press, 2003, s. 61-62; Rookhuijzen, age, s. 122-136; 140-143 dn. 378; Diodoros'a (XI. 12. 3) göre, Kserkses donanma komutanı Megabates'i yanına çağırtıp ondan Yunan donanmasına karşı yelken açmasını ve denizde onlarla savaşmasını istemiştir. Kralın emriyle Magnesia'ya gelen Megabates, burada çıkan firtına sonucunda 300'den fazla savaş gemisiyle çok sayıda nakliye gemisini ve başka gemiyi de kaybetmiştir. Ancak Herodotos'un verdiği donanma komutanları içerisinde Megabates ismi geçmemektedir.

${ }^{35}$ Hdt. VII. 192. 1.

${ }^{36}$ Hdt. VII. 194. 1-196. 1.

${ }^{37}$ Aphetai'nin lokasyonu için birkaç yer öne sürülmüş olsa da bunlardan en çok kabul göreni Artemision'dan doğrudan görülebildiği, 80 stadionluk mesafesinin uygunluğu ve iyi bir liman ve su kaynağına sahip olduğundan modern Platania sahilidir. Bkz. Rookhuijzen, age, s. 140.

38 Tarn, agm, s. 216; Perslerin kayb1 konusunda bkz. J. B. Bury, A History of Greece to the Death of Alexander the Great, London 1956, s. 273-274; Hignett, age, s. 167; Balcer, age, s. 254; A. Bowen, "The Place That Beached a Thousand Ships", The Classical Quarterly, Vol. 48, No. 2, 1998, s. 357-360.

${ }^{39}$ Cawkwell, age, s. 104; Hammond, "The Expedition of Xerxes", s. 548.
} 
yelken açtılar..."40 ifadesi yukarıda bahsettiğimiz meselenin çözümü için bir hayli önemlidir. Herodotos'a göre, Yunan donanmasının Artemision'dan Khalkis'e gidişi 3 Yunan keşif gemisinin ele geçirilmesinden sonra yaşanan korkunun bir etkisidir. Ancak aşağıda değinileceği üzere, Yunanlılar Pers ordu ve donanmasına ait doğru bilgilere zaten sahip olduklarından ötürü bu durum olası görünmemektedir. ${ }^{41}$ İleri sürülen bir diğer nedense, Euboia etrafını dolaşacak olan düşman gemilerini engelleme çabasıdır. Ancak bu durumda da Yunanlıların Pers donanmasına ait 200 geminin Euboia etrafından hareket edeceğini ${ }^{42}$ nasıl öğrendiği ve tüm donanmanın neden Artemision'dan ayrıldığı sorularıyla karşılaşırız. Herodotos'un Artemision Savaşı öncesindeki anlatımına bakıldığında Yunanlılar'ın 200 geminin hareket haberini alabilmesi için üç yolun olduğu anlaşılmaktadır: Skiathos Adası'ndan Artemision'a gönderilen ateş işaretleri; ${ }^{43}$ Sandokes komutasındaki 15 geminin Yunanlılar tarafindan ele geçirilmesi ${ }^{44}$ ve Perslere ihanet eden Skioneli Skyllias'1n verdiği bilgi. ${ }^{45}$ Eğer Herodotos'un anlatımındaki kronoloji doğruysa Yunanlıların haber kaynağı, Skiathos'tan gönderilen işaretlerdir. Fakat Skyllias'ın getirdiği haber karşısında Yunanlıların gösterdiği tepki de bir hayli ilginçtir. ${ }^{46}$ Haber kaynağının Skyllias'ın aksine ${ }^{47}$ Sandokes komutasındaki filonun olma ihtimali daha inandırıcıdır. Kanaatimiz Yunanlıların bahsi geçen haberi, ne zaman ve ne şekilde almış olursa olsun tüm donanmanın stratejik önemdeki Artemision'u bırakıp gitmesinin beklenecek bir hareket olmadı ̆̆ı yönündedir. Aynı zamanda Leonidas ve kuvvetlerinin Thermopylai'de olup olmaması da bu düşünceyi değiştirmeyecektir. Öyle ki Leonidas ile Eurybiades'in savaşla ilgili gelişmeleri, birbirine haber vermek amaciyla hazırda gemi bekletmesi ve kara gücünün yenilgisinden sonra donanmanın Artemision'dan ayrılma kararı $1{ }^{48}$ donanma ve kara gücünün sık1 bir işbirliği içerisinde olduğuna işaret etmektedir. Dahası Yunan donanmasının hem Euboia'ya gözcüler yerleştirmesi hem de Sandokes komutasındaki filoyu yakalaması onların mücadeleye hazır olduğunun bir işaretidir.

Volume 12

Issue 5

October 2020

Herodotos'un (VII. 183. 1) anlatımına farklı bir yorum getiren araştırmacılardan biri olan Sidebotham, Yunanlıların Pers donanmasından korkmuş gibi görünüp düşmanı tuzağa çekmek istediklerini öne sürmüştür (Harita 1) ${ }^{49}$ Eğer Yunanlılar, Persleri Oreos'un güneyindeki dar alana çekip orada savaşmak istemişse o zaman da Yunanlıların savaş süresince niçin bu yönde bir girişimde bulunmadığı sorusu akla gelmektedir. Bu noktada Sidebotham, ilk geri çekilişte planlanan hareketin başarısız olduğunu ve Yunanlıların buna bir kez daha teşebbüs etmediklerini iddia etmiştir. ${ }^{50}$ Yine de onun bu anlatımına karşın, gerek Atina gemisinin Peneios Ağzı'na kadar kaçması veya diğer iki Yunan keşif gemisinin hareketi gerekse Pers donanmasının tamamının Artemision’a gelmeyişi bu çekilişin stratejik bir yönünün olmadığını düşündürmektedir.

\footnotetext{
${ }^{40}$ Hdt. VII. 183. 1.

${ }^{41}$ Hdt. VII. 146. 1-147. 1; Lazenby, "The Strategy of the Greeks in the Opening Campaign of the Persian War", s. 275.

${ }^{42}$ Hdt. VIII. 6. 1-10. 3.

${ }^{43}$ Modern testler, ateş işaretlerinin dağ zirveleri arasında $200 \mathrm{~km}$ kadar görülebildiğini göstermiştir (Strauss, age, s. $18)$.

${ }^{44}$ Hdt. VII. 194. 1-196. 1.

${ }^{45}$ Lazenby, "The Strategy of the Greeks in the Opening Campaign of the Persian War", s. 282-283; Herodotos'un (VIII. 8. 1-3) anlatısına göre, Aphetai'de sayım yapıldığı esnada önceden beri Yunan tarafına geçmek isteyen ama uygun bir zaman bulamayan Skioneli Skyllias, Perslere ihanet edip onların planlarını Yunanlılara açıklamıştır. Skyllias'ın Persler'den ayrılmasının nedenlerine ilişkin bkz. Burn, age, s. 397.

${ }^{46}$ Hdt. VIII. 9. 1.

${ }^{47}$ Hignett, age, s. 182-183.

${ }^{48}$ Hdt. VIII. 21. 1.

${ }^{49}$ Sidebotham, agm, s. 182-186.

${ }^{50}$ Agm, s. 182-184.
} 
Meselenin çözümü için önemli bir nokta da Euboia etrafını dolaşacak gemilerin ne zaman hareket etmiş olduğudur. Herodotos, firtına sonrasında Aphetai'de tekrar bir araya gelen Perslerin Artemision'daki Yunanlıların gece karanlığından yararlanıp Euripos yönünde kaçmasını engellemek istediğini ve bunun için ana filodan 200 gemiyi ayırdığını belirtmiştir. ${ }^{51}$ Plana göre 200 gemi, Yunanlılara görünmeden Skiathos Adası'nın arkasından dolaşıp Geraistos Burnu'na (Euboia Adası'nın güneybatı ucu) oradan da Euripos'a ulaşacak ve düşmanın arkasını tutacaktır. Pers donanmasına ait gemiler de doğrudan ilerleyip Artemision'daki Yunan filosuna saldıracaktır. Böylelikle Euripos yönünde geri çekilemeyen Yunanlılar, iki güç arasında kalmış olacaktı. Fakat 200 gemi, Euboia kıyısındaki "Oyuklar" diye tabir edilen yerde yakalandıkları bir firtınada yok olmuştur. ${ }^{52} \mathrm{Bu}$ noktada iki hususu belirtmekte fayda vardır. Bunlar Herodotos'un 200 geminin Aphetai’ye ulaştıktan sonra ayrıldığı iması ve filonun Yunanlılara görünmeksizin Skiathos'un arkasından dolaştığı ifadesidir. ${ }^{53}$ Her ne kadar Herodotos'un anlatımını esas alan bazı araştırmacılar, 200 geminin Aphetai'de, yani firtına sonrasındaki dördüncü ya da beşinci gün ayrıldığını iddia etmiş ${ }^{54}$ olsalar da Bury ve Myres haklı bir şekilde bunun aksini savunmuşlardır. ${ }^{55}$ Doğrusu modern araştırmacılar, Pers gemilerinin çevresi en az $450 \mathrm{~km}$ olan Euboia'yı dolaşması için 60 saat kesintisiz bir şekilde yelken açması gerektiğini düşünmektedir. ${ }^{56}$ $\mathrm{Bu}$ görev doğrultusunda bir geminin öngörülemeyen olasılıklar bir yana, günde 15 saat yol almas1 gerektiğini kabul edersek bunun için en az 4 gün gereklidir. Bu durum Herodotos tarafından bizatihi şöyle açıklanmıştır: “... [Persler] Yunanlılara hemen o gün saldırmak niyetinde değillerdi; hatta Euboia'nın çevresinin dolaşıldiğını gösteren işareti almadan önce saldirmayacaklardi...". ${ }^{57}$ Buradan Pers donanmasının uygulanan plan dâhilinde Euboia'ya gönderilen 200 geminin yolculuğunu tamamlaması için onlara gerekli olan süreyi tanıdıkları anlaşılmaktadır. Dolayısıyla 200 geminin firtına öncesinde ana filodan ayrılmış olduğu açıktır. ${ }^{58}$ Aynı zamanda Aphetai'deki Perslerin iki gün süren mücadelesi incelendiğinde Artemision'a yönelik herhangi bir saldırıya yeltenmedikleri görülmektedir ve bu durum Herodotos'un ifadesini desteklemektedir. ${ }^{59}$ Zira Pers donanması, Yunanlıları kuşatacak olan 200 geminin uygun konuma geçmesini bekleyip onların işaretiyle saldırıya geçecektir.

Peki, Persler 200 geminin ayrılma kararını ne zaman vermişti? Herodotos'un (VII. 183. 1) anlatımından sanki keşif gemileriyle birlikte 200 geminin de aynı anda hareket halinde olduğu anlamı çıkmaktadır. Birçok araştırmacı da Herodotos'un bu anlatımını kabul etmiştir. ${ }^{60}$ Fakat alınan kararın Perslerin gönderdiği 10 keşif gemisinin Yunanlılara dair elde ettiği istihbarat raporlarına dayanması daha olasıdır.

İkinci husus ile ilgili olarak Herodotos, her ne kadar 200 geminin sanki görünmemek amaciyla Skiathos Adası'nın arkasından dolaştığını belirtmiş olsa da Yunanlı gözcülerin durumdan yine de haberdar olacağı bilinmelidir. Zira 200 gemi, Aphetai'den ayrılmış olsaydı bile yaklaşık 16 $\mathrm{km}$ uzaklıkta ${ }^{61}$ bulunan Artemision'daki gözcülerin dikkatinden kaçmazdı. Dolayısıyla, ne Skiathos'tan gönderilen ateş işaretlerinin ne de Sandokes komutasındaki filodan alınacak bilginin bir önemi kalmış olurdu. Dahası Artemision'dan ne kadar fazla gemi ayrılırsa Perslerin lehine

${ }^{51}$ Hdt. VIII. 6. 1-7. 2.

${ }^{52}$ Rookhuijzen, age, s. 143-145.

${ }^{53}$ Hdt. VIII. 7. 1-2.

${ }^{54}$ Grundy, age, s. 342-343; How-Wells, age, s. 372-373.

${ }_{55}^{55}$ Bury, agm, s. 89-93; Myres, age, s. 255-257.

${ }^{56}$ Rookhuijzen, age, s. 146-147; Cawkwell, age, s. 93.

${ }^{57}$ Hdt. VIII. 7. 2.

${ }^{58}$ Hdt. VIII. 7. 1-2.

${ }^{59}$ Hdt. VIII. 8. 1-9. 1.

${ }^{60}$ Bury, agm, s. 93-94; Myres, age, s. 257; Strauss, age, s. 18-19.

${ }^{61}$ Hdt. VIII. 8. 2. 
bir durum oluşturacakt1. ${ }^{62}$ Bu noktada 200 gemi, Herodotos'un bahsettiğinin aksine acaba doğrudan Atina'ya saldırıya geçmeyi mi planlamıştı? Kuşkusuz, bunun düşüncesi dahi Yunanlılar üzerinde psikolojik anlamda muazzam bir baskı yaratmış olmalıdır.

Herodotos Artemision'a gelmiş olan Yunanlıların Aphetai'ye yanaşmakta olan düşman gemilerinin çokluğunu ve yayılan düşman kuvvetlerinin büyüklügünü görünce korkuya kapılıp ikinci defa Yunan kıyılarına doğru çekilmeyi düşündüklerini ifade etmiştir. ${ }^{63}$ Bu düşüncenin farkına varan Euboialılar, Eurybiades'ten çocuklarını ve evlerini güvenli bir yere taşıyıncaya kadar bir süre daha bu kıyılarda kalmalarını istemiştir. Eurybiades tarafindan istekleri kabul edilmeyen Euboialılar, bu sefer Themistokles'i donanmanın kalması ve savaşa Euboia önünde girmesi yönünde ikna edip ona 30 talanton gümüş vermiştir. ${ }^{64}$ Themistokles, bu miktardan sanki kendisininmiş gibi 5 talantonu Eurybiades'e ve 3 talantonu da Artemision'dan uzaklara yelken açmayı düşünen ve 40 trieresle Atinalılardan sonra ikinci büyük filoya sahip olan Korinthoslu amiral Adeimantos'a verip Yunan gemilerinin geri çekilmesini engellemiştir. Bu arada Themistokles, geri kalan 22 talantonu (132.000 drakhmai) kendisi için ayırmıştır. ${ }^{65}$

Herodotos'a göre, Yunan donanmasının geri çekilme düşüncesinin asıl nedeni yukarıda da belirttiğimiz gibi Pers korkusudur. Fakat öncesinde de bahsettiğimiz üzere, Küçük Asya'dan ${ }^{66}$, Hellespontos' $\tan ^{67}$ ve sefer süresince sempatizan sakinlerden alınan istihbarat raporları Yunanlılara, Artemision'da savaşmaya karar vermeden önce, en azından MÖ 481 yılının sonbaharından itibaren, Pers donanmasının büyüklügü hakkında bilgi sağlamıştır. ${ }^{68}$ Ayrıca Yunanlılar, Akte Yarımadası üzerinde üç yıldır devam eden ve muazzam bir iş olan kanal çalışmasının sonuçlarını da tahmin etmiş olmalıydılar. ${ }^{69}$ Dahası Persler donanma hareketlerini gizleyemezlerdi. Bununla birlikte, Perslerin donanmalarının tespit edilmesini engellemek adına çok tehlikeli olan Yunan kıyılarında geceleyin yolculuk yapması yahut açık denize yelken açması da pek olası görünmemektedir. Bir yandan triereslerin ön tedarik hazırlığı ve mürettebatın dinlenmesi için kıyılara gereksinimi olduğundan açık denizin uygunsuzluğu ${ }^{70}$ diğer yandan Artemision'daki ilk mücadelenin Yunanlılar tarafından başlatılma girişimi ${ }^{71}$ Herodotos'un anlatımının güvenilirliğini zayıflatmaktadır. ${ }^{72}$

\footnotetext{
${ }^{62}$ Hdt. VIII. 8. 1-3; Lazenby, age, s. 128.

${ }^{63}$ M. B, Wallace, "Herodotus and Euboia", Phoenix, Vol. 28. No. 1, 1974, s. 32.

${ }^{64}$ Hdt. VIII. 4. 1-2; Wallace, agm, s. 22-25.

${ }^{65}$ Hdt. VIII. 5. 1-3; Plut. Them. VII. 4-6; Plutarkhos, Bioi Paralelloi: Aristides, Trans., B. Perrin, Loeb Classical Library, Cambridge, Mass.-London 1914, II. 2, IV. 2; Moralia XI. 867 c; Grundy, agm, s. 215-216; Wallace, agm, s. 22-25; Balcer, age, s. 253.

${ }^{66}$ Hdt. VII. 146. 1-3.

${ }^{67}$ Hdt. VII. 147. 2-3.

${ }^{68}$ Hdt. VII. 20. 1; Lazenby, "The Strategy of the Greeks in the Opening Campaign of the Persian War”, s. 268; Balcer, age, s. 227.

${ }^{69}$ Balcer, age, s. 227, 230.

${ }^{70}$ Güvertesi bir hayli dar olan triereslerde, kuşkusuz bir ya da iki günlük yiyecek taşınabilmekteydi. Bunun çözümü ise, mürettebata izin vermek ve kendi yiyeceklerini almaya göndermekti. Bilhassa, görev esnasındayken gemilerin karadan uzaklaşmasına imkân yoktu. Açık deniz, baştan sona kadar mürettebatla dolu hafif ve uzun savaş gemileri için uygun değildi. Bununla birlikte filo komutanları, her gece gemilerin karaya çekilebileceği, mürettebatın rahatlıkla yemek yiyip dinlenebileceği yerler bulmak zorundaydı. Üstelik bu yerler, çarşıya sahip bir yerleşim yerine yakın olmalıydı; çünkü mürettebat, gemileri bir kere sahile çektikten sonra pazara gidecek, yiyecek satın alacak, pişirmek için geri getirecek ve gemilerin yanında yiyecekti. Bkz. L. Casson, Antik Çağda Denizcilikve Gemiler, Çev: G. Ergin, Homer Yayınları, İstanbul 2002, s. 73-74. Bu konuda ayrıca bkz. Thuk. VIII. 95. 4.

${ }^{71}$ Hdt. VIII. 9. 1, 14. 1-2.

${ }^{72}$ Sidebotham, agm, s. 181; C. G. Starr, Antik Çă̆da Deniz Gücü, Çev: G. Ergin, Homer Kitabevi, İstanbul 2000, s. 28 .
} 
Yunan donanmasının bu geri çekilmeme kararını, Themistokles tarafından verilen rüşvete bağlayan Herodotos'un aksine Hammond, verilen kararın stratejik değerlendirmelerden kaynaklandığını iddia etmiştir. ${ }^{73}$ Yazara göre, donanma Oreos Kanalı girişini kontrol ettiği sürece Pers donanması Thermopylai'deki ordunun arkasına askeri kuvvet gönderemezdi ve ordu, Thermopylai'yi elinde tuttuğu sürece Pers kara birlikleri Artemision'dan donanmanın geri çekilme hattı yönünde Euripos'un dar boğazını tehdit edemeyeceğinden ötürü, Artemision ve Thermopylai'deki güçler birbirine bağımlıydı. Eurybiades bu yüzden donanmayı geri çekmeyi reddetmiş̧ir. Zira bunu yaparsa Leonidas ve birlikleri kuşatılabilir ya da yok olabilirdi. ${ }^{74}$ Her ne kadar bu stratejik bağlantı doğru olsa da geri çekilme düşüncesinin Pers korkusundan daha ziyade donanma komutanlarının endişesinden ve bilhassa onların birbirlerine karşı güvensizliğinden kaynaklanmış olduğu kanaatindeyiz. Herodotos'un vurguladığı gibi, Themistokles'in özellikle birlikten ayrılmak için direnen Korinthoslu Adeimantos'a "Medlerin kralından alabileceğinden daha büyük bir hazine vereceğim"75 diyerek onun gemisine gümüş göndermesi, stratejik değerlendirmeler kadar var olan huzursuzluk ortamına işaret etmektedir. Bilhassa, 113 gemilik önemli bir donanma gücüne sahip Peloponnesoslu komutanlar1 ${ }^{76}$ bir arada tutabilmek için Themistokles'in rüşvet vermesi akla yatkındır. Bu bakımdan var olan huzursuzluğun esas nedeni, Salamis Savaşı sırasında açıkça ortaya çıkan Isthmos'a çekilme düşüncesi olmalıdır. Zira Isthmos Peloponnesoslular tarafından en iyi savunma noktası olarak kabul edilmiştir. Bilhassa Kserkses'in ordusu, Thermopylai'ye yaklaştığı zaman Leonidas'ın ordusundaki Peloponnesoslular Isthmos'a çekilmek istemişlerdir. ${ }^{77}$ Aynı şekilde Yunan donanması Salamis'e gelmeden, Thermopylai düşer düşmez Peloponnesosluların Isthmos'ta savunma duvarları inşa ettikleri ve burada, Leonidas'ın kardeşi Kleombrotos'un komutası altında ordugâh kurdukları Herodotos tarafından açık bir şekilde ifade edilmiştir. ${ }^{78}$ Neticede Themistokles, bu hareketiyle MÖ 494 yılında Lade Deniz Savaşı'nda yaşanan benzeri bir dağılmanın ${ }^{79}$ önüne geçmekle birlikte, bundan sonraki ilk hedef konumundaki Atina'ya karşı da olası bir düşman saldırısını engellemeye çalışmış olabilir.

Herodotos'a göre, Thermopylai'deki kara ordusuna destek vermek amaciyla Artemision'a gelen Yunan donanması şu halklardan oluşmaktadır:

"Yüz yirmi yedi gemi donatmış olan Atinalılar (bu gemilerde tayfa olarak Atinalılarla birlikte Plataialılar da bulunuyordu, denizcilik sanatında usta değillerdi ama yiğit ve çalışkandılar); safa kırk gemi sokmuş olan Korinthoslular, yirmi gemi donatmış olan

\footnotetext{
${ }^{73}$ Hammond, "The Expedition of Xerxes", s. 552.

${ }^{74}$ Hammond, "The Expedition of Xerxes", s. 552; Evans, "Notes on Thermopylae and Artemisium", s. 368-369.

${ }^{75}$ Hdt. VIII. 5. 2.

${ }^{76}$ Hignett, age, s. 156.

${ }^{77}$ Hdt. VII. 139. 1-6, 207. 1, VIII. 40. 2, 49. 1-50. 2, 56. 1-64. 1; Diod. XI. 15. 2-3; Plut. Them. IX. 3; J. R, Wiseman, "A Trans-Isthmian Fortification Wall", Hesperia, Vol. 32, No. 3, 1963, s. 248-275; A. R. Hands, "On Strategy and Oracles, 480/479, The Journal of Hellenic Studies, Vol. 85, 1965, s. 58-59; N. Robertson, "The True Meaning of the 'Wooden Wall'", Classical Philology, Vol. 82, No. 1, 1987, s. 4-5; R. Garland, Athens Burning: The Persian Invasion of Greece and the Evacuation of Attica, Baltimore 2017, s. 54 vd.; Plutarkhos, bundan dolay1 Atinalıların kendilerini ihanete uğradıklarını sayıp öfkeye kapıldıklarını ve aynı zamanda yalnızlıkları karşısında çaresizlik içerisinde oldukları bilgisini vermiştir (Plut. Them. IX. 4). Isthmos'a çekilme düşüncesi askeri açıdan mantıklı bir karardır; şu bakımdan ki Attika'nın kuzey sınırı uzun ve birkaç noktada savunmasızdır ve Attika'nın kuzeydoğu kıyısı boyunca Yunan donanmasının korunabileceği uygun bir üs yoktur. Ancak Atina ve Megara için acımasız bir karardır; acımasız çünkü sığınmacılar mal ve mülklerini geride bırakmak zorunda kalacaktır. Bkz. Hammond, "The Expedition of Xerxes", s. 568.

${ }^{78}$ Hdt. VIII. 71. 1-72. 1; Hignett, age, s. 126-127; Ayrıca bkz. Diod. XI. 16. 3; Çoğu Peloponnesos kenti, Med sempatizanı olduğundan Isthmos'taki çalışmalara destek vermemiştir. Helotslar (heilōtai) ve diğer bağımlı gruplar, Perslere kurtarıcı gözüyle bakmaktadır. Bkz. M. A, Dandamaev, Political History of the Achaemenid Empire, Leiden 1989, s. 208-209.

${ }^{79}$ Hdt. VI. 13. 1-14. 3.
} 
Megaralılar, Khalkisliler, Atinalıların kendilerine emanet etmis olduklart yirmi geminin tayfalarını temin etmişlerdi; Aiginalılar on sekiz, Sikyonlular on iki, Lakedaimonlular on, Epidauroslular sekiz, Eretrialılar yedi, Troizenliler beş, Styralılar iki gemiyle katıllyorlardl. Keoslular iki trieres ve ayrica elli kürekli [pentekontoros] iki gemi. Opus Lokrislileri de ellişer kürekli yedi gemilik bir takviye yollamışlardır. Artemision Burnu'nda savaşan uluslar bunlardır ve her birinin verdiği gemi sayısını da bildirdim. Artemision Burnu'nda toplanmış olan gemilerin toplam sayısı elli kürekli gemiler dışında iki yüz yetmiş birdi" ${ }^{80}$

Bu halklardan oluşan Artemision'daki toplam donanma gücü, dokuz pentekontoros dişında 271 -yahut 324- trieres di. ${ }^{81}$ Diodoros da ayrım yapmaksızın donanmanın, 140 tanesi Atinalilara ait olmak üzere 280 trieresten meydana geldiğini belirtirken; ${ }^{82}$ Demosthenes (MÖ 384-322) de 300 sayısını vermiştir. ${ }^{83}$ Eğer her bir geminin 200 kişi taşıdı $\breve{~} 1$ kabul edilip gemi başına, en az 10 hoplites (ağır silahlı piyade) ve 4 okçu da bu sayıya dâhil edilirse toplam donanma gücü yaklaşık 54.000 kişiye ulaşmaktadır. ${ }^{84}$ Ayrıca metinden Yunan donanmasının esas gücünün Atina, Korinthos ve Aigina kentlerinin trieres filolarından meydana geldiği açıkça görülmektedir. Doğal olarak Atina'nın bu gücü, Themistokles'in MÖ 483 yılında başlatmış olduğu başarılı gemi inşa programının bir sonucudur. ${ }^{85} \mathrm{Bu}$ noktada önemli bir husus ise, Atinalıların triereslerine mürettebat bulmakta zorluk çektiğidir. Atinalılar bu mürettebat sorununu Plataialı ve Khalkislilerin yardımıyla çözmüşlerdir. ${ }^{86}$

Yunan donanması tıpkı orduda olduğu gibi, Artemision'da da Sparta'nın komutası altındadır. Bunun nedeni, müttefiklerin Atinalı komutanları istememesi ve tasarlanan sefere katılmayıp dönüp gideceklerini bildirmeleridir. Bilhassa Korinthos, uzun zamandan beri Atina'nın ticari rakibidir ve bu rekabet, Artemision Savaşı'na kadar sürmüştür. Buna ek olarak Aigina, Atina'nın en amansız düşmanı olarak bilinmektedir ve Kserkses'in seferinin başlangıcına kadar iki taraf arasındaki savaş devam etmiştir. ${ }^{87}$ Aynı zamanda Korinthos ve Aigina, Sparta'nın sadık müttefikleridir. Her ne kadar birlik donanmasındaki gemilerin çoğunluğu, Atinalıların olsa da donanma komutasının Atinalılara verilmesi kabul görmemiştir. Buna rağmen Themistokles, ortak amaç uğruna kavgaları durdurmayı başarmıştır ve nihayetinde Spartalı Eurykleides oğlu Eurybiades, birlik donanmasının komutanı (nauarkhos $=$ vav́ $\alpha \rho \chi o \varsigma$ ) olarak görevlendirilmiştir. ${ }^{88}$

\footnotetext{
${ }^{80}$ Hdt. VIII. 1. 1-2. 1.

${ }^{81}$ Hdt. VIII. 14. 1; How-Wells, age, s. 235, 363; Morrison-Coates-Rankov, age, s. 55.

${ }^{82}$ Diod. XI. 12. 4.

${ }^{83}$ Demosthenes, Orations I-XVII, XX: Olynthiacs; Philippics; Halonnesus; Minor Public Orations; Speech Against Leptines, vol. I, Trans., J. H. Vince, The Loeb Classical Library, Cambridge, Mass.-London 2004, On the Navy XIV. 29.

${ }^{84}$ Souza, age, s. 49.

${ }^{85}$ MÖ 483 yılında Atinalılar Laurion'daki kamu madenlerinden çok zengin bir gümüş damarının keşfedilmesiyle finansal anlamda önemli bir zenginlik elde etmişlerdir. Bu doğrultuda Themistokles, elde edilen bu geliri öncesinde olduğu gibi yurttaşlar arasında dağıtmak yerine yeni bir donanma inşası için kullanılması yönünde halkı ikna etmiştir. Konuya ilişkin olarak bkz. Hdt. VII. 144. 1-3; Thuk. I. 18. 2, 93. 3-5, Aristoteles, Athenaion Politeia (Atinalıların Devleti), çev., A. Çokona, Türkiye İş Bankası Kültür Yayınları, İstanbul 2019, XXII. 7; Cornelius Nepos, II. 2. 6-7 'Themistokles'; Polyainos, Stratagemata: Stratagems of War, Trans., P. Kerentz and E. L. Wheeler, Vol. I-II. Ares Publishers, Chicago 1994, I. 30. 1-2; Plut. Them. VII. 1, X. 1-2; Frank J. Frost, "Themistocles' Place in Athenian Politics", California Studies in Classical Antiquity, Vol. 1, 1968, s. 117-118; Meiggs, age, s. 123-126; C. J. Haas, "Athenian Naval Power before Themistocles", Historia, Bd. 34, H. 1, 1985, s. 29-30; Lazenby, age, s. 83-85.

${ }^{86}$ Evans, "Notes on Thermopylae and Artemisium", s. 390; Lazenby, age, s. 112; Megara'nın askeri ve donanma gücü için bkz. B. R., MacDonald, "The Megarian Decree", Historia, Bd. 32, H. 4, 1983, s. 391-93.

${ }^{87}$ Hdt. V. 82. 1-89. 3, VI. 87. 1-93. 1, VII. 145. 1; A. J, Podlecki, “Athens and Aegina”, Historia, Bd. 25, H. 4, 1976, s. 396-413.

${ }^{88}$ Hdt. VIII. 2. 1-3. 2; Thuk. I. 18. 2; Diod. XI. 12. 4; Dandamaev, age, s. 202; Hignett, age, s. 97; Plutarkhos'a (Them. VII. 2-3) göre, Themistokles kendi komutasını Eurybiades'e teslim ettiği gibi Atinalıları yatıştırıp boyun eğmelerini sağlamıştır. Buna karşılık, eğer bu savaşta kendilerini yiğit erkekler olarak gösterecek olurlarsa bundan sonra
} 
Kserkses, Thessalia ve Akhaia'yı geçtikten sonra kampını Trakhis topraklarındaki Malis'te kurmuştur ve Yunanlılar da Leonidas'ın komutası altındaki bir kuvvetle Thermopylai'de onları beklemektedir. ${ }^{89}$ Herodotos, Kserkses'in Thermopylai'deki 4 günlük bekleyişini düşmanın kaçmasını umut etmeye bağlamaktadır. ${ }^{90}$ Ancak Yunanlıların daha önceden Sardeis'e casuslar gönderdiği bilinmektedir ${ }^{91}$ ve bundan dolayı Yunanlılar, birliklerini Thermopylai'ye göndermeden çok önce Pers güçlerinin büyüklüğü hakkında yeterince bilgiye sahip olmalıdır. Herodotos'un aksine Kserkses'in bu süre zarfinda ${ }^{92}$ Thermopylai'de kendi donanması için beklediği ileri sürülebilir ${ }^{93}$ ve söz konusu Pers kralının planı, Yunan donanmasının yok edilmesinden sonra Thermopylai'deki Yunan mevzilerine saldırıda kara gücüne destek olmaktır. ${ }^{94}$ Kimilerine göre, çıkarma yapan gemiler korunmadığı sürece saldırıya açık olacağından ve Pers donanmasının, Artemision'da Yunan triereslerini uzak tutmak için bir çabası olmadığından ötürü bu mümkün görünmemektedir. ${ }^{95}$ Daha mantıksal bir şekilde Sidebotham, Kserkses'in Thermopylai önünde süvari ${ }^{96}$ ya da tüm yürüyüş kolunun ana kuvvete katılmış ve onları saldırı grupları halinde yeniden organize etmek adına 4 gün boyunca beklemiş olduğunu ileri sürmüştür. ${ }^{97}$ Eğer firtına çıkmamış olsaydı ordu ve donanma aynı gün belirlenen noktalarda olacakt1.

\section{2- Savașın Stratejik ve Taktiksel Yönleri}

Herodotos'a göre, Perslere ihanet eden Skyllias muhtemelen bir tekneyle Artemision'a gelip düşmanın hem Aphetai'de batan ${ }^{98}$ hem de Euboia etrafını dolaşacak olan gemileri konusunda Yunanlıları bilgilendirmiştir. ${ }^{99} \mathrm{Bu}$ haber üzerine Yunanlılar, aralarında yaptıkları görüşmeler neticesinde o gün bir yere ayrılmadıklarını göstermek için Artemision'da kalmaya ve gece yarısından sonra 140 km'lik bir yolculuğa çıkıp ${ }^{100}$ Euboia' yı dolaşacak olan gemileri karşılamaya karar vermiştir. ${ }^{101}$ Fakat Herodotos Yunanlıların kendilerine doğru, herhangi bir düşman kuvvetinin gelmediğini gördüklerinde Aphetai'deki Pers filosuna saldırmaya karar verdiklerini belirtmiştir. ${ }^{102} \mathrm{Bu}$ doğrultuda hem mücadele yöntemlerini kanıtlama hem de diekplous ${ }^{103}$ manevrasını deneme arzusunda olan Yunanlılar, öğleden sonra Pers donanmasına saldırmıştır. Bunun üzerine Kserkses'in komutanları, kendilerine doğru gelen bu küçük filoyu gördüklerinde kolay bir zafer kazanacaklarını düşünüp derhal karşı saldırıya geçmiştir. Akabinde daha fazla

\footnotetext{
Yunanlıları gönüllü olarak onlara boyun eğmeye ikna edeceği konusunda söz vermiştir. Böylece Yunanistan'ın kurtarılmasında en etkili insan olduğu kabul edilmiştir ve Atinalılara hem yiğitlikte düşmanlarına hem de yüce gönüllülükte dostlarına üstün gelmiş olma şanını kazandırmıştır.

${ }^{89}$ Hdt. VII. 196. 1-203. 2; Burn, age, s. 378-381; W. K. Pritchett, Studies in Ancient Greek Topography, Vol. V, University of California Press, London 1985, s. 199-204; Rookhuijzen, age, s. 150-153. Herodotos, Thermopylai Savaşı neticesinde ölenler için yapılan mezar anıtında Peloponnesos'tan gelen dört bin kişinin orada üç milyon Persli ile savaştığını söylemiştir. Bu konuda bkz. Hdt. VII. 228. 1; Diod. XI. 4. 6; Hignett, age, s. 116.

${ }^{90}$ Hdt. VII. 210. 1.

${ }^{91}$ Hdt. VII. 145. 2-146. 3

${ }^{92}$ Muhtemelen Kserkses'in geldiği gün ve donanmasının firtınaya yakalandığı üç gün.

${ }^{93}$ Lazenby, "The Strategy of the Greeks in the Opening Campaign of the Persian War", s. 268. dn. 1.

${ }^{94}$ Hignett, age, s. 143; Sidebotham, agm, s. 178.

${ }^{95}$ Evans, "Notes on Thermopylae and Artemisium", s. 398.

${ }^{96}$ Burn, age, s. 392.

${ }^{97}$ Sidebotham, agm, s. 178.

${ }^{98}$ Hdt. VII. 192. 1.

${ }^{99}$ Hdt. VIII. 8. 1-3; Pausanias, Periegesis tes Hellados: Description of Greece, Trans., W. H. Jones-H. A. Ormerod, Vol. I-VI, New York 1918, X. 19. 1.

${ }^{100}$ Hammond, "The Expedition of Xerxes", s. 553.

${ }^{101}$ Hdt. VIII. 6. 1-10. 3; Diod. XI. 12. 3; Burn, age, s. 395-397.

102 Hdt. VIII. 9. 1; Bu plan değişikliğinin muhtemelen hava koşulundan kaynaklandığı öne sürülmüştür. Bkz. Bury, agm, s. 86; Evans, "Notes on Thermopylae and Artemisium", s. 397.

103 J. F. Lazenby, “The Diekplous”, Greece \&Rome, Vol. 34. No. 2, 1987, s. 169-177.
} 
sayıda ve hizlı gemilere sahip olan komutanlar, periplous ${ }^{104}$ olarak bilinen manevra doğrultusunda Yunan filosunun etrafinı çevirmiştir. Bununla birlikte bu durumdan memnun olanlar da bir Atina gemisi ele geçirip Büyük Kral'dan ilk ödülü alacak olmanın hoşnutluğu içerisindedir. ${ }^{105}$ Böylece Persler ve Yunanlılar arasında 3 gün süren deniz savaşının ilk mücadelesi başlamıştır. Herodotos, mücadeleyi şöyle izah etmiştir:

"Yunanlılar birinci işareti alınca önce gemilerinin burnunu barbarlara çevirdiler; gemilerin kıçları içeriye dönük olmak üzere bir çember biçimini [kyklos manevrası] aldılar. Ikinci işarette davrandllar, dar bir alanda ve her yandan çevrilmiş olmalarına bakmayarak dosdoğru saldırlya [diekplous] geçtiler. Orada barbarların otuz gemisini [mahmuzlama sonrasında] ve bu arada düşman saflarında büyük ünü bulunan ve Salamis kralı Gorgos'un kardeşi olan Khersis oğlu Philaon adındaki komutanı ele geçirdiler. Düşmandan ilk gemiyi alan Yunanl, Aiskhraios oğlu Lykomedes ismindeki Atinall idi ve bu yiğitliği için ödül almıştı...". ${ }^{106}$

Yunan donanması, muhtemelen düşman donanmasının onarım işlerinin ve organizasyonun devam ettiği sıralarda ${ }^{107}$ onların savaş taktikleri ve manevra yeteneklerini öğrenmek üzere alaca karanlıktan yararlanıp ani bir saldırı gerçekleştirmiştir. Denizdeki ilk mücadele, karanlığın çökmesiyle sonuçsuz kalınca her iki taraf da kamp yerlerine geri çekilmiştir. Fakat gece çıkan ve sabaha kadar devam eden firtına, ${ }^{108}$ pek çok Pers gemisinin yok olmasına neden olmuştur. Ertesi sabah, Attika kıyılarını koruyan ${ }^{109}$ ya da büyük olasılıkla öncesinde Artemision'daki ana filodan ayrılan 53 (ya da 50) ${ }^{110}$ triereslik bir kuvvet gelmiştir. ${ }^{111}$ Bu gelen kuvvetler, Euboia tepelerindeki gözcülerden öğrendikleri ${ }^{12} 200$ geminin firtınada battı̆̆ haberini de getirmiştir. ${ }^{113}$ Neticede gerek 53 triereslik filonun gelişi gerekse 200 geminin uğradığı felaket haberi, Yunanlıların cesaretini arttırmıştır. Böylelikle cesareti artan ve yüksek morale sahip olan Yunanlılar, bir

Volume 12

Issue 5

October

\footnotetext{
104 Yunanlıların periplous yani, "çevreden dolaşmak" adını verdikleri bu manevrada asıl amaç düşman gemilerinin etrafindan dolaşıp onların saflarının ucuna ulaştıktan sonra arkadan çevirerek pupa kısmından vurmaktı. Bkz. Casson, age, s. 79-80.

${ }^{105}$ Hdt. VIII. 10. 1-3; W. W. How, "Arms, Tactics and Strategy in the Persian War", The Journal of Hellenic Studies, Vol. 43, 1923, s. 117, 128-132.

${ }^{106}$ Hdt. VIII. 11. 1-2; Kyklos, gemilerin mahmuzları dışa dönük olmak üzere filonun savunma amaçlı oluşturduğu bir tür savaş manevrasıdır. Konuya ilişkin olarak bkz. Morrison-Coates-Rankov, age, s. 53 dn. 2; Rees, age, s. 39; Plutarkhos'un (Them. XV. 3) Salamis Savaşı'nda Lykomedes'e atfettiği kahramanlığın aksine Herodotos'un anlatımının gerçeği yansıtması daha olasıdır. Bkz. J. A. R. Munro, "Xerxes' Invasion of Greece", The Cambridge Ancient History, Vol. IV, Ed. J. B. Bury, S. A. Cook, F. E. Adcock, Cambridge University Press, Cambridge 1926, s. 289; Hignett, age, s. 184 dn. 4; How-Wells, age, s. 238.

${ }^{107}$ Burn, age, s. 397.

${ }^{108}$ R. Lattimore, "The Second Storm at Artemisium", The Classical Review, Vol. 53, 2009, s. 57-58.

${ }^{109}$ Evans, "Notes on Thermopylae and Artemisium", s. 399.

${ }^{110}$ Diod. XI. 13. 2.

${ }^{111}$ Lazenby, "The Strategy of the Greeks in the Opening Campaign of the Persian War", s. 273-274; Hignett'a göre, Atina son üç yıldır devasa bir gemi inşa programının içerisinde olduğundan ötürü, bu gemiler, Artemision'a yelken açacak durumda değildi veya belki de Atinalılar mürettebat için yeterli insan toplamakta zorluk çektiğinden gemiler geç ulaşmıştı (Hignett, age, s. 187). Bununla birlikte, bazı araştırmacılar bu gemilerin başlangıçta Eurybiades’in komutası altında olduğunu belirtip akabinde Skiathos'tan ateş işaretlerinin verilmesiyle Khalkis'e geri gönderildiğini iddia etmiştir. Konuya ilişkin olarak ayrıca bkz. Bury, agm, s. 83-97; J. A. R. Munro, "Some Observations on the Persian Wars: The Campaign of Xerxes", Journal of Hellenic Studies, Vol. 22, 1902, s. 307-312; Tarn, agm, s. 218; How-Wells, age, s. 372-377.

112 Bury, agm, s. 94.

${ }^{113} \mathrm{Bu}$ noktada kimi araştırmacılar bu felaketi, Pers donanmasının Magnesia' da yaşadığı aynı firtınaya bağlarken kimisi de başka bir firtınanın neden olduğunu savunmuştur (Myres, age, s. 258).
} 
önceki gün olduğu gibi aynı vakitte Kilikia gemilerine saldırıp onları batırmıştır. ${ }^{114}$ Aynı zamanda Yunan donanmasının küçük bir kayba uğradığı da söylenebilir. ${ }^{115}$

Herodotos'a göre üçüncü gün Persli kaptanlar, gerek az sayıdaki Yunan gemisinin kendilerine vermiș olduğu zarara katlanamadıklarından gerekse Kserkses'in öfkesinden korktuklarından ötürü, bulundukları yerde beklemek yerine saldırıya geçmiştir. ${ }^{116}$ Sidebotham, Herodotos'un bu söylediklerine karşı çıkıp Kserkses'in donanmasına olan öfkesinin Yunanlılar karşısında alınan mağlubiyetten daha ziyade Thermopylai'de bekleyen güçlerine yardım yapılmamasından kaynaklanmış olabileceğini iddia etmiştir. ${ }^{117}$ Belki de Kserkses' in kızgınlığının asıl nedeni, 200 geminin felaket haberiydi. Herodotos, üçüncü günde Persler tarafından başlatılan saldırıya dair şunları aktarmaktadır:

\begin{abstract}
"Kserkses'in denizcileri savaş düzeninde ilerledikleri sırada, Yunanlılar Artemision'da dinleniyorlardı. Barbar filosu, yay biçimini almıştı; öbürlerini bir kuşatma manevrasıyla kıstırmak istiyordu. O zaman Yunanlılar çıktılar ve savaşa katıldılar. Bu deniz savaşında her iki taraf da eşit başarıya sahipti. Zira büyüklüğü ve sayı üstünlüğü Kserkses ’in filosu için zararlı oluyordu, gemiler serbest davranamıyorlar birbirleri üstüne düşüyorlardl. Bununla beraber iyi tutunuyorlar, boyun eğmiyorlardl; zira Persler bu kadar az gemi önünde geri basmayı onurlarına yediremiyorlardı. Pek çok Yunan gemisi şimdiden batmış, pek çok asker düşmüşı̈̈; barbarların kayıpları gerek gemi, gerek insan bakımından daha büyüktü. Devam eden savaş, her iki tarafin ayrılıp kendi yerlerine çekilmesiyle son buldu". ${ }^{118}$
\end{abstract}

Artemision Savaşı genel anlamda değerlendirildiğinde bilhassa birinci ve üçüncü gün yapılan mücadele bağlamında savaş stratejisi noktasında bazı bilgilere ulaşılmaktadır. Bir geminin en savunmasız yeri yan ve pupa tarafi olduğundan Yunanlılar, Artemision'da mahmuzlamaya uygun saldırı taktiklerinden birisi olan diekplousu uygulamıştır ve düşman gemilerini bordalamaktan ziyade onları kullanılmaz hale getirmeyi amaçlamıştır. ${ }^{119}$ Mahmuzlu gemiler, burun kısımlarında bronzla kaplanmış boynuz gibi bir çıkıntıya sahiptir ve genellikle, bütün mahmuz yaban domuzu olarak şekillendirilmiş olup domuzun burnu da ön yüzü oluşturmaktadır. ${ }^{120}$ Mahmuzlama için hız ve manevra yeteneği gerektiğinden olabildiğince hafif gemiler tercih edilmiştir ve deniz piyadelerinin sayısı en aza (sadece 10 mızrakçı ve 3 ya da 4 okçuya) indirilmiştir. ${ }^{121}$ Aynı zamanda deniz savaşlarında mahmuzlama kadar mürettebatın yeteneği ve disiplininin de önemli ${ }^{122}$ bir unsur olduğu unutulmamalıdır.

Herodotos'un gemi ve denizci üstünlüğüne sahip Pers donanmasına dair “... Bu düşünce ile ortada [Yunanlıları] çember içine aldılar" ${ }^{123}$ anlatımı düşmanın saldırı biçimini göstermesi bakımından önemlidir. Bu hareket, periplous olarak bilinen bir saldırı manevrası olup Pers donanması tarafından savaş esnasında uygulanmaya çalışılmıştır. Genel olarak metinde (Hdt.

\footnotetext{
${ }^{114}$ Hdt. VIII. 12. 1-14. 2; Pausanias, X. 19. 2; Lazenby, age, s. 141.

${ }^{115}$ Myres, age, s. 260.

${ }^{116}$ Hdt. VIII. 15. 1

${ }^{117}$ Hignett, age, s. 189; Sidebotham, agm, s. 184.

118 Hdt. VIII. 16. 1-3.

${ }^{119}$ Morrison-Coates-Rankov, age, s. 53-54; Hammond, “The Expedition of Xerxes", s. 554; Strauss, age, s. 21-22.

${ }^{120}$ Hdt. III. 59. 3; Mahmuzun bu şekle gelmesi büyük olasılıkla savaş tecrübesinin bir sonucudur. Sivri uçlu mahmuz, teknede delik açarak düşman gemisini etkisiz kılar; ancak delik içinde sıkışma riskini de beraberinde getirmektedir. Eğer bu olursa ve saldırıyı yapan gemi kendini çabucak kurtaramazsa, çevredeki düşman gemileri için savunmasız bir hedef haline gelmektedir. Kör uçlu mahmuz, ağır darbe vurur ve eğer bu vuruş uygun biçimde yapılırsa tekneyi parçalamaz, ama darbe alan noktanın en uzağındaki armuzları bile zayıflatır. Bu konuda bkz. Haas, agm, s. 33; Casson, age, s. 61.

${ }^{121}$ Casson, age, s. 77

122 Morrison-Coates-Rankov, age, s. 55.

${ }^{123}$ Hdt. VIII. 10. 1.
} 
VIII. 16. 1-3) bahsedildiği üzere, Pers donanması önce yarım ay diğer bir tabirle hilal biçimi alarak düşmanı iki kanattan kuşatmayı planlamıştır. Ancak diekplous tekniğini başarıyla uygulayan Yunan gemileri, ikinci işarette doğrudan kuşatmayı yarıp dar alanda Pers gemilerinin manevra kabiliyetlerini kaybetmesine ve kargaşa içerisinde gemilerin birbirine çarpmasına neden olmuştur. Özellikle Perslerin sayı üstünlüğü dar alanda dezavantaja dönüştüğünden az sayıdaki; ancak sıkı düzen içerisinde yer alan Yunan gemilerine yanaşamayan düşman gemileri, saldırıya açık hale gelmiştir. Bu bakımdan zayıf alanda Pers hattını yaran Yunanlılar, çemberi aştıktan sonra geri dönüp düşman gemilerini ya mahmuzlayıp geri çekilmiştir ya da bir tarafındaki kürek sırasını tamamen kırmıştır. ${ }^{124}$ Aynı zamanda bu mücadele esnasında, Herodotos'un “Atinalıların gemilerinin yarısı kullanılmaz hale gelmişti" 125 ifadesinden Pers donanmasının Yunan gemilerini mahmuzladığı ve ağır kayıplara neden olduğu anlaşılmaktadır.

Diğer taraftan Yunanlıların Artemision'da uyguladıkları bir diğer savaş stratejisi ise, iki günlük süreçte açık denizde Pers donanması ile doğrudan karşılaşmak yerine ${ }^{126}$ öğle vaktine kadar bekleyip sonrasında saldırıya geçmeleridir. Hâlihazırda Pers kuvvetleri, Artemision karşısındaki birçok limanı ele geçirip dağınık halde demirlemiş durumdaydı ${ }^{127} \mathrm{Bu}$ doğrultuda Yunanlılar, minimum risk alıp diğer gemiler desteğe gelmeden önce olabildiğince düşman gemisini hasara uğratmayı amaçlamıştır. Muhtemelen, böyle sürpriz ve ani bir saldırıda Yunanlılar Persleri hazırlıksız yakaladığı gibi ${ }^{128}$, akabinde daha hızlı olan düşman gemilerinden ${ }^{129}$ de kaçıp gece karanlığından yararlanarak sığınabilecek uygun yerler bulmayı umut etmiştir. Böylece onlar, moral yüksekliği ve güven içerisinde kendi üslerine geri dönmüştür (Harita 2). ${ }^{130}$

Herodotos'a göre, savaşın bitmesi her iki tarafı da bir hayli mutlu etmiştir. ${ }^{131}$ Gerçekleşen son mücadelede en çok başarıyı gösterenler Yunanlılar tarafında Atinalılar; Pers donanması içerisinde ise, 5 Yunan gemisini mürettebatıyla birlikte ele geçiren Misırlılar olmuştur. Açıkçası Mısırlı denizciler, bordalamada önemli bir başarı elde etmişlerdir. ${ }^{132}$ Savaşın sonucuyla ilgili olarak Herodotos, her ne kadar iki tarafın ağır kayba uğradığını belirtmiş olsa da Perslerin kayıplarının gerek gemi gerekse insan bakımından daha fazla olduğunu bildirmiştir. ${ }^{133}$ Buna karşın Artemision'un Yunanlılar için bir gurur kaynağı olduğunu belirten Plutarkhos, zaferi hırsızlık ve bir rüşvet işi olarak gören Herodotos'u Atinalıların bu ihtişamını küçümsemesinden dolayı eleştirmiştir. ${ }^{134}$ Diodoros ise, her iki tarafın da tam bir zafer kazanamadığına dikkat çekmiştir. ${ }^{135}$ Bununla birlikte Balcer, Artemision'daki mücadelenin Yunanlılara paha biçilmez bir deneyim sağlamış olduğunu ve Pers deniz üstünlüğü söylencesini çökerttiğini ifade

\footnotetext{
${ }^{124}$ Myres, age, s. 260; Morrison-Coates-Rankov, age, s. 54-55; Casson, age, s. 79-80.

${ }^{125}$ Hdt. VIII. 18. 1.

${ }^{126}$ Hignett, age, s. 188; H. Delbrück, Warfare in Antiquity: History of the Art of War, Vol. I, Trans.: Walter J. Renfroe, University of Nebraska Press, Lincoln and London 1990, s. 99-100.

127 Diod. XI. 12. 5-6

${ }^{128}$ Tarn, agm, s. 217-218; Burn, age, s. 397.

${ }^{129}$ Hdt. VII. 179. 1, VIII. 60a

${ }^{130}$ Hignett, age, s. 185-188; Myres, age, s. 260.

${ }^{131}$ Hdt. VIII. 18. 1.

${ }^{132}$ Hdt. VII. 89. 3; VIII. 17. 1; Hignett, age, s. 190; How-Wells, age, s. 375-376.

${ }^{133}$ Hdt. VIII. 16. 3; Delbrück, age, s. 98-99; Rees, age, s. 25.

${ }^{134}$ Plut. Moralia, XI. 867 c-f; Ayrıca bkz. Aristophanes, Lysistrata, Thesmophoriazusae, Ecclesiazusae, Plutus, vol. III, Trans., B. B. Rogers, The Loeb Classical Library, Cambridge, Mass.-London 1946, Lysistrata, 1250-1254; Isokrates, Isocrates, G. Norlin, vol. I-II, The Loeb Classical Library, Cambridge, Mass.-London 1980, Panegyricus 90; Suda, Suidae Lexion, Suda Lexicon, Ed. G. Zorgos, vols. I-VI, Create Speace 2009, Lexicon 439 s.v. 'Simonides'; Plut. Them. VIII. 2-3.

${ }^{135}$ Diod. XI. 12. 6.
} 
etmiştir. ${ }^{136}$ Tarn da Artemision Savaşı'nın gerek gemi sayısı gerekse savaşın bu kadar uzak ve rakip sahada gerçekleşmesinden dolayı antik dünyanın en büyük deniz savaşı olduğuna dikkat çekmiştir. ${ }^{137}$ Netice itibariyle Pers donanması her ne kadar Artemision'da büyük kayıplara uğramış olsa da Salamis Savaşı'nda çok zorlu bir düşman olarak Yunanlıların karşısına çıkmıştır. Yine de Yunanlılar Artemision'daki savaş neticesinde Pers kuvvetlerinin yenilebileceğini görmüştür.

Artemision'da Atina gemilerinin yarısının zarar görmesi üzerine, Yunanlılar savaşı bırakıp Yunanistan'a çekilmek istemiştir. Buna karşın Themistokles, eğer Ionia ve Karia birliklerini Persler'den ayırmayı başarabilirlerse geri kalan kuvveti yenebileceklerine inanmaktaydı. Bu doğrultuda komutanları bir araya getiren Themistokles, onlara Kserkses'in en iyi müttefiklerini elinden alabileceğini düşündüğ̈̈ bir hileye sahip olduğunu bildirmiştir. Buna ek olarak komutanlara, Euboialılara ait sürüden herkesin istediği kadar yararlanmasını ve bunun için de kıyıda bir ateş yakılmasını tavsiye etmiştir. Böylelikle Persleri aldatıp zarar görmeden Yunanistan'a dönebileceklerdi. Bununla birlikte Themistokles, Yunanlılar için bir yiyecek kaynağı olarak gördügü Euboialılara ait sürüleri ${ }^{138}$ aynı zamanda bir tehlike olarak da görmüş olabilir. Zira gemilere bindirilecek sürüler, hızlarını azaltacağından bu durum hem Yunanlılar hem de Euboialılar için büyük bir risk demektir.

Yunanlılar, Themistokles'in söylediği şeyleri yaparken Thrakhis’te bekleyen gözcü Abronikhos da Artemision'a gelmiştir. Abronikhos'un gelişiyle birlikte Yunanlılar, Thermopylai'nin düşüşünü ${ }^{139}$ ve Perslerin kara yoluyla Atina'ya ilerleyişini öğrenmiştir. ${ }^{140}$ Zaten geri çekilmeyi planlayan Yunanlılar, ${ }^{141}$ artık Artemision' da kalmalarının kendileri için bir felaket olabileceğini bildiklerinden ötürü oradan ayrılıp Salamis'e çekilmeyi kararlaştırmıştır. ${ }^{142}$ Onların çekilmesi üzerine Pers donanması, ilk önce Artemision'a oradan da Histiaia kentine hareket etmiştir. ${ }^{143}$ Themistokles, Artemision'dan ayrılmadan önce Atina gemilerinin en hızlılarını ${ }^{144}$ alıp içilebilir su kaynaklarına doğru gitmiştir ve orada, ertesi gün Ionialıların okuması için taşlara mesajlar kazınmasını istemiştir. ${ }^{145}$ Aslında Themistokles, Ionialılara Yunan tarafına geçmeleri

136 J. M. Balcer, “The Persian Wars against Greece: A Reassessment”, Historia, Bd. 38, H. 2, 1989, s. 137.

137 Tarn, agm, s. 219.

${ }^{138}$ Hdt. VIII. 19. 1-20. 2.

${ }^{139}$ Herodotos'a göre, Leonidas ve ordusu Thermopylai'de Kserkses'in 20.000 adam kaybetmesine neden olmuștur. Thermopylai Savaşı için ayrıca bkz. Hdt. VII. 204. 1-239. 4; Diod. XI. 4. 1-10. 4; Plut. Moralia, XI. 866 a-867 c; Aristophanes, Lysistrata 1255-1260; Isokrates, Paneg. 90; W. K, Pritchett, "New Light on Thermopylai", American Journal Archaeology, vol. 62, No, 2, Apr., 1958, s. 203-213; J. R. Grant, "Leonidas' Last Stand", Phoenix, Vol. 15, No. 1, 1961, s. 14-27; Hignett, age, s. 141-148; J. A. S. Evans, "The 'Final Problem' at Thermopylae", Greek, Roman and Byzantine Studies, vol. 5, No. 4, 1964, s. 231-237; J. Hart, Herodotus and Greek History, Croom Helm, London 1982, s. 93-95; Lazenby, age, s. 134-138, 141-149; N. G. L. Hammond, "Sparta at Thermopylae", Historia, Bd. 45, H. 1, 1996, s. 1-20; Mikalson, age, s. 63-66; Carey, age, s. 79 vd.

140 Hdt. VIII. 21. 1-2; L. Lloyd Jones-James Robson, Ctesias' History of Persia: Tales of the Orient, Routledge, London and New York 2010, FGrHist 688 F13. (27) 'Ktesias'; Diod. XI. 6. 3-11. 6; Marcus Iulianus Iustinus, M. Iuliani Iustini Epitoma Historiarum Phillippicarum Pompei Trogi, Epitome of the Phillippic History of Pompeius Trogus, Trans., J. C. Yardley, With introduction and explanatory notes by R. Develin, Atlanta 1994, II. 11. 1-19; Plut. Them. IX. 1; Polyainos, Stratagemata: Stratagems of War, I. 32. 1-3; Tzetzes, Historiarum Variarum, Chiliades, Ed. T. Kiessling, Leipzig 1826, I. str. 958-972; Dio Khrysostomos, Orationes: Dio Chyrsostom. Trans., W. Cohoon- H. L. Crosby, London, New York 1932-1953; Cambridge, Mass.-London 2006, XXXVII. 18; Lysias, II. 31-33; Strauss, age, s. 33-37.

${ }^{141}$ Hdt. VIII. 18. 1.

142 Diod. XI. 13. 3-4; Plut. Moralia, XI. 867 c; Evans, "Notes on Thermopylae and Artemisium", s. 390-391; Sidebotham, agm, s. 185.

${ }^{143}$ Lazenby, "The Strategy of the Greeks in the Opening Campaign of the Persian War", s. 265.

${ }^{144}$ Morrison-Coates-Rankov, age, s. 53, 95.

${ }^{145}$ Hdt. VIII. 19. 1-22. 3. 
yönünde açıkça çağrı yaparak bu savaşın Ionia İsyanı (MÖ 499) sırasında yaptıkları yardımdan ${ }^{146}$ kaynaklandığına vurgu yapmıştır. Hatta Themistokles, Ionialılar'dan Karialıları da savaştan çekilmeleri yönünde ikna etmelerini istemiştir. Böylelikle Ionialılar, ya taraf değiştirip Yunan kuvvetlerine katılır ya da bunu yapmazdı; ancak bu durumda Persler, onların sadakatinden şüphelenirdi. ${ }^{147}$ Herodotos'un açıklamalarına bakıldığında öncesinde Perslere sığınan Limnoslu Antidoros dışında geri kalan Yunanlıların Kserkses'e sadık kaldıkları görülmektedir. ${ }^{148}$ Thermopylai'nin düşmesi ve Yunan donanmasının kıyı sularına çekilmesinden sonra, tüm orta Yunanistan Isthmos'a kadar Perslere açık hale gelmiştir. Persler Doris, Phokis, Lokria ve orta Yunanista'ın diğer bölgelerini işgal edip direniş gösteren farklı kent ve kasabaları da yok etmiştir. Buna ek olarak, Boiotia halkı Perslerin tarafına geçmiştir. ${ }^{149}$ Neticede Pers ordusu, Attika ve Atina'ya doğru karşı konulmaksızın ilerlerken donanma da herhangi bir engelle karşılaşmaksızın Euripos üzerinden Phaleron Limanı'na ulaşmıştır. ${ }^{150}$

\section{Sonuç:}

Yunan kuvvetlerinin Salamis ile Isthmos için sadece zaman kazanmak adına Artemision ve Thermopylai'de savaşması mantıklı değildir. Zira bir yandan Atina ile çevredeki kentlerin tahliyeye yönelik bir hazırlık yapmamas ${ }^{151}$ diğer yandan Isthmos'ta savunma hattı için Yunanlılar arasında yaşanan görüş ayrılıkları ${ }^{152}$ göz önüne alındığında bu düşünce olası görünmemektedir. Sidebotham'in Yunanlılar, Pers donanmasını Maliakos (Malian) Körfezi ve Euripos ağzına çekmeye çalışmıştı ${ }^{153}$ görüşünün aksine; Yunanlıların asıl amacı, büyük olasılıkla Aphetai'ye dağınık halde demirlemiş olan Pers filolarına pasif bir şekilde ara ara stratejik saldırılar düzenlemekti. Yukarıda da açıklanmaya çalışıldığı üzere, bunun en önemli kanıtı denizdeki ilk iki saldırının Yunanlılar tarafından öğleden sonra gerçekleştirilmiş olup son deniz savaşının Oreos Kanalı'nın güneyinde değil, Herodotos'un aktardığı gibi, Artemision'da yaşanmas $1^{154}$ olarak gösterilebilir. Eğer Yunanlıların düşmanı kesin bir şekilde yok etmek gibi bir amacı olsaydı Pers donanmasıyla doğrudan savaşa girmesi gerekirdi.

Yukarıda da bahsettiğimiz üzere, Yunanlıların Artemision'dan ilk geri çekilişi (VII. 183. 1) araştırmacılar tarafından çoğunlukla firtınayla ilişkilendirilip kendi güvenlikleri yönünde bir hareket olduğu iddia edilmiştir. Buna karşın Skiathos'tan gönderilen işaretlerin Perslere ait 10 keşif gemisinin yaklaştığına dair bir uyarı olması da mümkündür. Belki de donanma, kendisini düşmana göstermemek adına belli bir mesafeye çekilme kararı almıştır. Buna bağlı olarak 200 gemilik Pers tehdidi haberinin, Skyllias'ın Yunanlılara sığınması ya da Sandokes komutasındaki filonun ele geçirilmesi ile ilişkilendirilmesi daha doğrudur. Birçok araştırmacının belirttiği gibi, Artemision'daki Yunan donanmasının bir kısmının Khalkis'i korumak üzere geri çekilmiş olması mantıklıdır. Bu doğrultuda askeri bir deneyime sahip olmayan Herodotos, gerçekleşen bu harekâtı tüm donanmaya atfetmiş olabilir. ${ }^{155}$ Buna göre, deniz savaşının ikinci gününde

${ }^{146}$ Hdt. V. 97. 1-3, 99. 1

${ }^{147}$ Hdt. VIII. 22. 1-3, IX. 98. 4; Plut. Them. IX. 1-2; Iustinus, II. 12. 1-8; Buna karşın West, böyle bir olayın gerçeklikten uzak olduğunu ve bunun büyük ölçüde sonraki olaylara dayanılarak yaratıldığını ifade etmiştir. Bkz. S. West, "Herodotus' Epigraphical Interest", The Classical Quarterly, Vol. 35, No. 2, 1985, s. 285-286.

${ }^{148}$ Hdt. VIII. 11. 3.

${ }^{149}$ Hdt. VIII. 31. 1-39. 2; Plut. Them. IX. 3; Dandamaev, age, s. 204.

${ }^{150}$ Hdt. VIII. 66. 1-67. 2.

${ }^{151}$ Hdt. VIII. 41. 1-42. 2; Diod. XI. 13. 4; Plut. Them. IX. 4, X. 1-6; Jameson, agm, s. 114; Lazenby, "The Strategy of the Greeks in the Opening Campaign of the Persian War", s. 264.

${ }^{152}$ Hdt. VII. 139. 1-6, 207. 1, VIII. 40. 2, 49. 1-50. 2, 56. 1-64. 1; Diod. XI. 15. 2-3; Plut. Them. IX. 3.

153 Sidebotham, agm, s. 177-182.

${ }^{154}$ Diod. XI. 13. 2.

${ }^{155}$ Bury, agm, s. 88-89; Myres, age, s. 257; Buna karşın Lazenby, bu tür bir bölünmede Yunan kuvvetlerinin gücünün azalacağını ve bundan dolayı düşman kuvvetlerine karşı yapılacak saldırının güçlü olamayacağını dile getirmiştir Bkz. 
Artemision'daki ana filoya katılan 53 trieres muhtemelen sonradan gönderilen takviye bir kuvvet değildi. Bu filonun amacı, belki de yedekteki diğer filoyla birleșip ${ }^{156}$ Khalkis'te Perslere ait 200 gemiyle bir mücadeleye girmekti ${ }^{157}$. Fakat bu filo, 200 geminin Euboia kıyılarında battığ haberini alır almaz yeniden Artemision'daki ana filoya katılmıştır. Bir diğer olasılık da Herodotos'un (VII. 183. 1) anlatıma bağlı bir hata yapmış olabileceğidir. Bu doğrultuda Herodotos, ilk çekilişin nedenini bildiğinden ötürü anlatım sırasında fark etmeksizin okuyucuya "Khalkis'e çekilme" sonucunu bildirmiş olabilir. Planlanan ama uygulanmayan ikinci çekiliş (VIII. 4. 1) ise, Pers korkusu yahut Euboia etrafinı dolaşan filonun tehdidine yönelik stratejik bir geri çekilmekten daha çok Yunanlı komutanların kendi aralarındaki anlaşmazlıktan kaynaklandığını düşündürmektedir. Son olarak Yunanlılar, Thermopylai'de alınan yenilgi neticesinde fiilen Artemision'dan çekilmek (VIII. 18. 1) zorunda kalmıştır.

Thermopylai ve Artemision, Yunanlılar açısından stratejik olarak seçilmiş ve onların amaçlarına uygun iki önemli noktadır. Bu doğrultuda Yunanlılara ait kara ve deniz gücü, birbirine bağlı hareket ederek Pers saldırısını engellemeye çalışmıştır. Bilhassa konum gereği Artemision, bir ön cephe olup gerek Oreos Kanalı'nın gerekse Euboia'daki müttefiklerin korunması açısından ayrı bir önem teşkil etmektedir. Bununla birlikte, Euboia'nın batısı ile Yunanistan anakarası arasındaki Euripos, Atina'ya ulaşım açısından kolay ve güvenli bir güzergâhtır. Dolayısıyla, Leonidas'ın görevi Thermopylai'deki geçidi tutmak iken Eurybiades, Artemision'da Pers donanmasına saldırıp düşman geçişini durdurmaya çalışmıştır. Buna ek olarak Artemision'a gönderilen donanmanın büyüklüğü, Yunanlıların orada Persleri sadece engelleme düşüncesinde olmadığına işaret etmektedir. Bu bağlamda Yunanlılar muhtemelen Pers donanmasına karşı ara ara ani ve stratejik saldırılar gerçekleştirip düşmanın daha fazla sayıdaki gemisini hasara uğratmayı amaçlamıştır. Böylelikle Yunanlılar, sayısal üstünlüğü azaltıp belki önceden planlanan ya da büyük olasılıkla savaş esnasında değişen koşullara (53 trieresin gelişi, Aphetai'deki büyük firtına, 200 geminin uğradığı felaket gibi) bağlı olarak pasif mücadeleyi bırakıp doğrudan ve kesin bir zafer elde etmek adına savaşa girmiştir.

\section{Kaynakça}

\section{Antik Kaynaklar}

Aristophanes, Lysistrata, Thesmophoriazusae, Ecclesiazusae, Plutus, vol. III, Translation, B. B. Rogers, The Loeb Classical Library, Cambridge, Mass.-London 1946.

Aristoteles, Athenaion Politeia (Atinalıların Devleti), çev., A. Çokona, Türkiye İş Bankası Kültür Yayınları, İstanbul 2019.

Cornelius Nepos, On the Great Generals of Foreign Nations (Ünlü Kişilerin Yaşamlarl), çev., Ü. Fafo Telatar, Arkeoloji ve Sanat Yayınları, İstanbul 2016.

Demosthenes, Orations I-XVII, XX: Olynthiacs; Philippics; Halonnesus; Minor Public Orations; Speech Against Leptines, vol. I, Trans., J. H. Vince, The Loeb Classical

Library, Cambridge, Mass.-London 2004.

Diodoros, Bibliotheke Historike: Diodorous of Sicily, Trans., C. H. Oldfather, vol. I-VI; C. H.

Lazenby, "The Strategy of the Greeks in the Opening Campaign of the Persian War", s. 276. Ayrica bkz. Evans, "Notes on Thermopylae and Artemisium", s. 399; Lazenby'in aksine, Yunan donanmas1 uygun zaman gelene kadar bekleyip düşmanla denizde nihai bir savaşa girmekten kaçınmış olabilir. Bu durumda Eurybiades'in esas amacının belli bir süre dâhilinde Pers donanmasını kesin bir yenilgiye uğratmaktan uzak olduğu söylenebilir.

${ }^{156}$ Hdt. VIII. 42. 1-2; 44. 1.

${ }^{157}$ Hdt. VIII. 4. 1. 
Sherman, vol. VII; C. B. Welles, vol. VIII; R. M. Geer, vol. IX-X; F. R. Walton, vol. XI-XII, The Loeb Classical Library, Cambridge, Mass.-London 1933-2004.

Dio Khrysostomos, Orationes: Dio Chrysostom, Trans., J. W. Cohoon- H. L. Crosby, London, New York 1932-1953; Cambridge, Mass-London 2006.

Herodotos, Historiae (Herodot Tarihi), çev., M. Ökmen, Türkiye İş Bankası Kültür Yayınları, İstanbul 2016.

Isokrates, Isocrates, Trans., G. Norlin, vol. I-II, The Loeb Classical Library, Cambridge, Mass.London 1980.

Lysias, Lysias, Trans., W. R. M. Lamb, Cambridge-Massachusetts 2000.

Marcus Iulianus Iustinus, M. Iuliani Iustini Epitoma Historiarum Phillippicarum Pompei Trogi, Epitome of the Phillippic History of Pompeius Trogus, Translation by J. C. Yardley, With Introduction and explanatory notes by R. Develin, Atlanta 1994.

Pausanias, Periegesis tes Hellados: Description of Greece, Trans., W. H. Jones-H. A. Ormerod, Vol. I-VI, New York 1918.

Plinius Secundus, Naturalis Historia, Natural History, Trans., J. H. R. Rackham, W. H. S. Jones, D. E. Eichholz, Vol. I-X, The Loeb Classical Library, Cambridge, Mass.-London 19381971.

Plutarkhos, Bioi Paralelloi: Themistokles, Trans., B. Perrin, The Loeb Classical Library,

Cambridge, Mass.-London 1914.

Volume 12

Issue 5

October

, Bioi Paralelloi:Aristides, Trans., B. Perrin, The Loeb Classical Library,Cambridge, Mass.-London, 1914.

, Bioi Paralelloi: Kimon, Trans., B. Perrin, The Loeb Classical Library, Cambridge, Mass.-London, 1914.

Plutarch's Moralia, Trans., F. C. Babbith- W. C. Helmbold, vols. I-XIV, Loeb Classical Library, Cambridge, Mass.-London 1928-1967.

Polyainos, Stratagemata: Stratagems of War, Trans., P. Kerentz and E. L. Wheeler. Vol. I- II. Ares Publishers, Chicago 1994.

Strabon, Geographika: The Geography of Strabo, Trans., H. L. Jones, Vol. I-VIII, The Loeb Classical Library, London, New York, 1917-1932.

Suda, Suidae Lexion, Suda Lexicon, Ed. G. Zorgos, vols. I-VI, Create Speace 2009.

Thukydides, Historiae (Peloponnesos Savaşı), çev., T. Gökçöl, Hürriyet Yayınları, İstanbul 1976.

Tzetzes, Historiarum Variarum, Chiliades, Ed. T. Kiessling, Leipzig 1826.

Vegetius, Epitoma rei Militaris, Epitome of Military Science, Trans., N. P. Milner, Liverpool University Press, Liverpool, 1996.

Vitruvius, De Architectura (Mimarlı Üzerine On Kitap), çev., S. Güven, Şevki Vanlı Mimarlık Vakfi Yayınları, İstanbul 2015.

\section{Modern Kaynaklar}

BALCER, J. M., The Persian Conquest of the Greeks 545-450 B. C., Konstanz 1995. 
J. M. "The Persian Wars against Greece: A Reassessment", Historia, Bd. 38, H. 2, 1989 , s. 127-143.

BORZA, E. N., "Timber and Politics in the Ancient World: Macedon and the Greeks", Proceedings of the American Philosophical Society, Vol. 131, No. 1, 1987, s. 32-52.

BOWEN, A., "The Place That Beached a Thousand Ships", The Classical Quarterly, Vol. 48, No. 2, 1998, s. 345-364.

BURN, A. R., Persia and the Greeks: The Defence of the West, c. 546-478 B.C. London 1962.

BURY, J. B., "The Campaign of Artemisium and Thermopylae", The Annual of the British School at Athens, Vol. 2, 1895/6, s. 83-104.

, A History of Greece to the Death of Alexander the Great, London 1956.

CAREY, C., Thermopylae, Oxford University Press, Oxford 2019.

CASSON, L., Antik Çağda Denizcilik ve Gemiler, Çev: G. Ergin, Homer Yayınları, İstanbul 2002.

CAWKWELL, G., The Greeks Wars: The Failure of Persia, Oxford University Press, Oxford, 2005.

CUSTANCE, R., War At Sea: Modern Theory and Ancient Practice, William Blackwood and Sons, Edinburg and London 1919.

DANDAMAEV, M. A, Political History of the Achaemenid Empire, Leiden 1989.

DELBRÜCK, H., 'Warfare in Antiquity: History of the Art of War', Vol. I, Trans.: Walter J. Renfroe, University of Nebraska, Lincoln and London 1990.

EVANS, J. A. S., "Notes on Thermopylae and Artemisium”, Historia, Bd. 18, H. 4, Aug. 1969, s. 389-406.

"The 'Final Problem' at Thermopylae", Greek, Roman and Byzantine Studies, Vol. 5, No. 4, 1964, s. 231-237.

FERRILL, A. "Herodotus and the Strategy and Tactics of the Invasion of Xerxes", The American Historical Review, Vol. 72, No. 1, Oct. 1966, s. 102-115.

FROST, Frank J., "Themistocles' Place in Athenian Politics", California Studies in Classical Antiquity, Vol. 1, 1968, s. 105-124.

GARLAND, R., Athens Burning: The Persian Invasion of Greece and the Evacuation of Attica, Baltimore 2017.

GRANT, J. R., “Leonidas' Last Stand”, Phoenix, Vol. 15, No. 1, 1961, s. 14-27.

GREEN, P., The Greco-Persian Wars, University of California Presss, Berkeley \& Los Angeles, 1996.

GRUNDY, G. B., “Artemisium”, Journal of Hellenic Studies, Vol. 17, 1897, s. 212-229.

, The Great Persian War and Its Preliminaries: A Study of the Evidence, Literary and Topographical, London 1901.

HAAS, C. J., "Athenian Naval Power before Themistocles", Historia, Bd. 34, H. 1, 1985, s. 2946. 
HAMMOND, N. G. L, "Sparta at Thermopylae", Historia, Bd. 45, H. 1, 1996, s. 1-20. , A History of Greece to 322 B. C., Oxford 1989.

"The Expedition of Xerxes", The Cambridge Ancient History, Vol. IV, Ed. John Boardman, N. G. L. Hammond, D. M. Lewis, Cambridge University Press, Cambridge 2008, s. 518-591.

HANDS, A. R., "On Strategy and Oracles, 480/479, The Journal of Hellenic Studies, Vol. 85, 1965, s. 56-61.

HART, J., Herodotus and Greek History, Croom Helm, London 1982.

HIGNETT, C., Xerxes' Invasion of Greece, Clarendon Press, Oxford 1963.

HOW, W. W.- J. Wells, A Commentary on Herodotus, Vol. I. (2000), II. (1991), Oxford.

HOW, W.W., "Arms, Tactics and Strategy in the Persian War, The Journal of Hellenic Studies, Vol. 43, 1923, s. 117-132.

JAMESON, M. H, "Waiting for the Barbarian: New Light on the Persian Wars, Greece\&Rome, Vol. 8, No. 1, Mar. 1961, s. 5-18.

JONES L. Lloyd-James Robson, Ctesias' History of Persia: Tales of the Orient, Routledge, London and New York 2010.

LATTIMORE, R., "The Second Storm at Artemisium", The Classical Review, Vol. 53, 2009, s. $57-58$

LAZENBY, J. F., The Defence of Greece 490-479 B. C., Aris\&Phillips, Warminster 1993. ,"The Diekplous", Greece\&Rome, Vol. 34. No. 2, 1987, s. 169-177.

,"The Strategy of the Greeks in the Opening Campaign of the Persian War", Hermes, Bd. 92, H. 3, 1964, s. 264-284.

MACAN, R. G., Herodotus: The Seventh, Eighth and Ninth Books, Cambridge University Press, Oxford 2010.

MACDONALD, B. R., “The Megarian Decree”, Historia, Bd. 32, H. 4, 1983, s. 385-410.

MANSEL, A. M, Ege ve Yunan Tarihi, Türk Tarih Kurumu, Ankara 2011.

MAURICE, F., "The Size of the Army of Xerxes in the Invasion of Greece 480 B. C", Journal of Hellenic Studies, Vol. 50, 1930, s. 210-235.

MEIGGS, R, Trees and Timber in the Ancient Mediterranean World, Oxford University Press, 1982.

MiKALSON, J. D., Herodotus and Religion in the Persian Wars, The University of North Caroline Press, 2003.

MORRISON, J. S., J. F. Coates, N. B. Rankov, The Athenian Trireme, Cambridge University Press, Cambridge 2000.

MUNRO, J. A. R, “Xerxes' Invasion of Greece”, The Cambridge Ancient History, Vol. IV, Ed. J. B. Bury, S. A. Cook, F. E. Adcock, Cambridge University Press, Cambridge 1926, s. 268- 316 
"Some Observations on the Persian Wars: The Campaign of Xerxes", Journal of Hellenic Studies, Vol. 22, 1902, s. 294-332.

MYRES, J. L., Herodotus: Father of History, Oxford University Press, Oxford 1999.

PODLECKI, A. J, “Athens and Aegina”, Historia, Bd. 25, H. 4, 1976, s. 396-413.

PRENTICE, W. K., "Thermopylae and Artemisium", Transactions and Proceedings of the American Philological Association, Vol. 51, 1920, s. 5-18.

PRITCHETT, W. K., Studies in Ancient Greek Topography, Vol. V, University of California Press, London 1985.

"New Light on Thermopylai", American Journal Archaeology, vol. 62, No, 2, Apr., 1958, s. 203-213.

REES, O, Great Naval Battles of the Ancient Greek World, Pen \& Sword 2018.

ROBERTSON, N, “The True Meaning of the 'Wooden Wall”, Classical Philology, Vol. 82, No. 1, 1987, s. 1-20.

ROOKHUIJZEN, J. Zacharias van, Herodotus and the Topography of Xerxes' Invasion: Place and Memory in Greece and Anatolia, Walter de Gruyter GmbH \& Co KG, 2018.

SACKS, K. S, "Herodotus and Dating of the Battle of Thermopylae", The Classical Quarterly, Vol. 26, No. 2, 1976, s. 232-248.

SIDEBOTHAM, S., "Herodotus on Artemisium", The Classical World, Vol. 75, No, 3, Jan.-Feb., 1982, s. 177-186.

SOUZA, Philip de, The Greeks and Persian Wars 499-386 BC, Routledge, New York and London 2012.

STARR, C. G., Antik Çağda Deniz Gücü, Çev: G. Ergin, Homer Kitabevi, İstanbul 2000.

STRAUSS, B., The Battle of Salamis: The Naval Encounter that Saved Greece - and Western Civilization, Simon \& Schuster, 2005.

TARN, W. W., "The Fleet of Xerxes”, The Journal of Hellenic Studies, Vol. 28, 1908, s. 202233.

WALLACE, M. B, “Herodotus and Euboia”, Phoenix, Vol. 28. No. 1, 1974, s. 22-44.

WEST, S., "Herodotus' Epigraphical Interest", The Classical Quarterly, Vol. 35, No. 2, 1985, s. 278-305.

WISEMAN, J. R, “A Trans-Isthmian Fortification Wall”, Hesperia, Vol. 32, No. 3, 1963, s. 248275. 


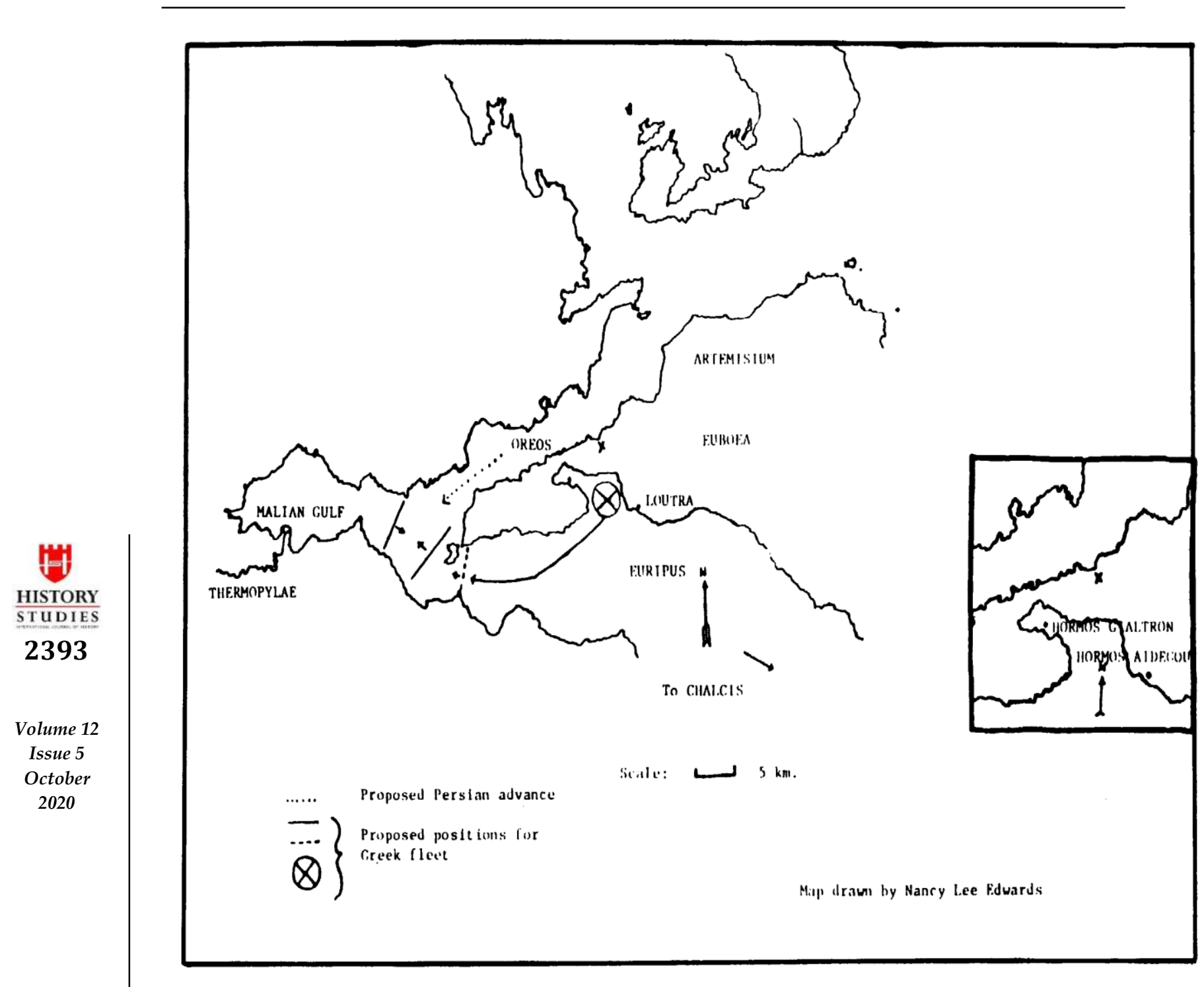

Harita 1. 


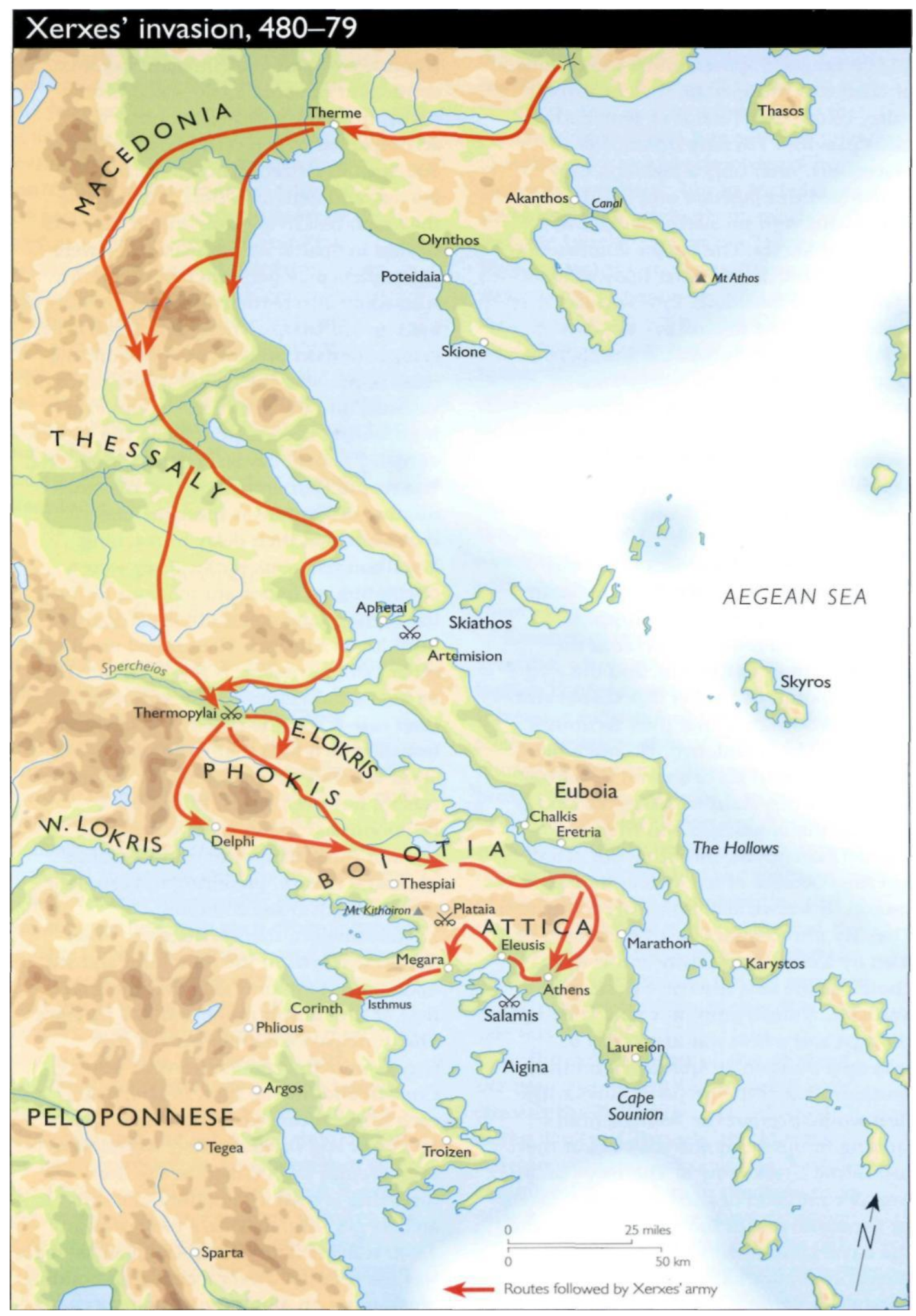

Volume 12

Issue 5

October

2020

Harita 2. 